ارزيابى مدلهاى شبكه عصبى مصنوعى و رگرسيون خطى جند گانه در تخمين دادههاى

گم شده جريان روزانه (مطالعه موردى: ايستخاه هيدرومترى سنته - استان كردستان)

محمد عيسىزاده، يروا محمدى * و يعقوب دين يزوه'

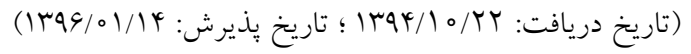

جكيده

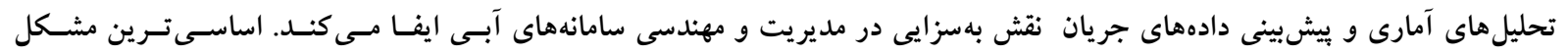

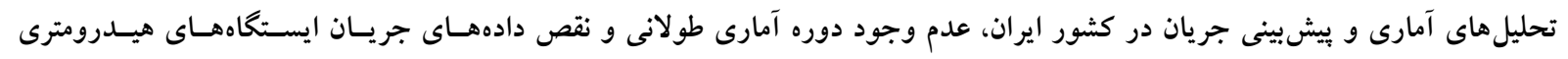

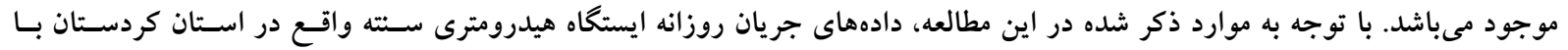

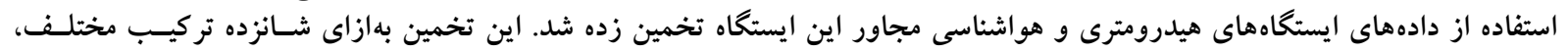

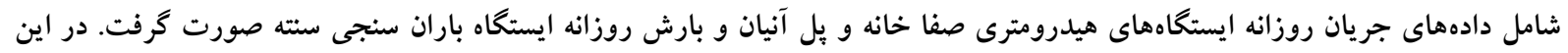

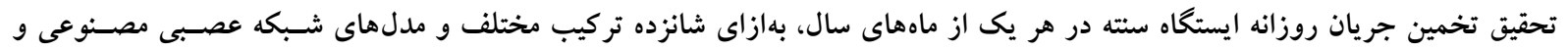

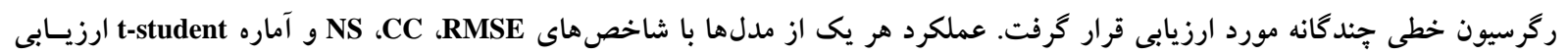

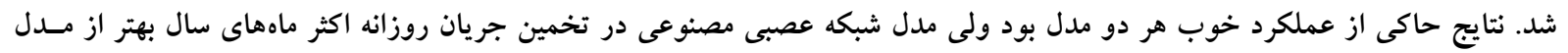

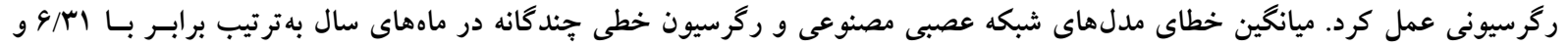

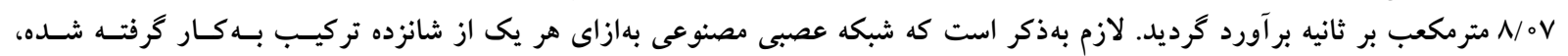

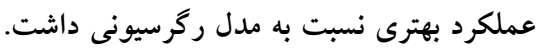

وازههاى كليدى: تخمين داده گمشده، شبكه عصبى، ركرسيون خطى جندگانه، ايستاه سته

أ. كروه مهندسى آب، دانشكده كشاورزى، دانشكاه تبريز

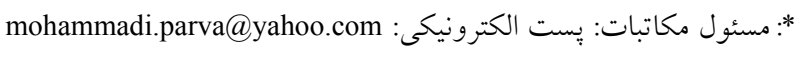


نشان داد مدل شبكههاى عصبى مصسنوعى از كـارايى مناسبـى

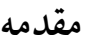

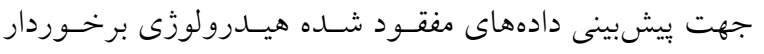

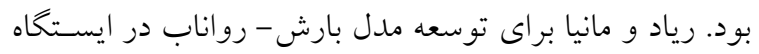

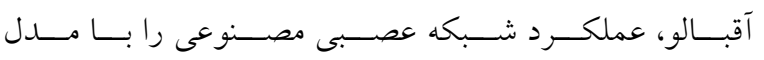

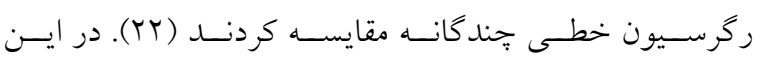

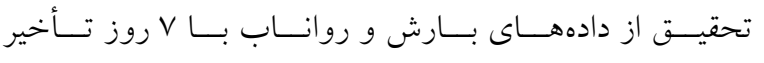

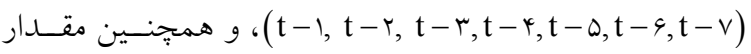

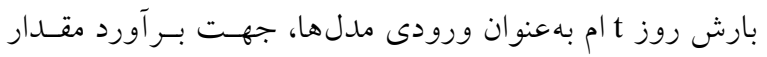
رواناب روز t ام (Q(t) استفاده شد. نتايج قابليت بيشتر شـبكه

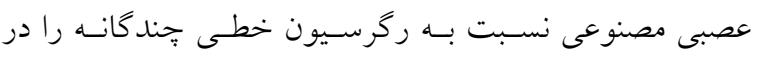

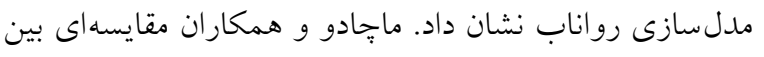

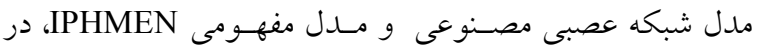
مقياس زمانى ماهانه جهت بيش بينى بـارش - روانـاب انجـام

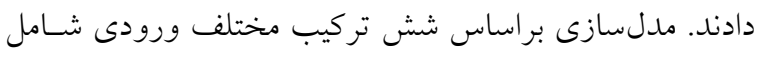

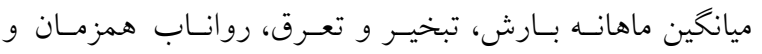

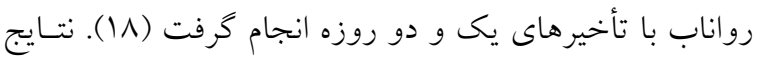

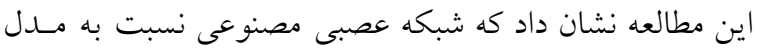
مفهـومى IPHMEN از دقـت بيشـترى در بهيشبينسى جريسان برخوردار بود. جوشى و وِاتال (01) جهت مدل سازى بـارش-

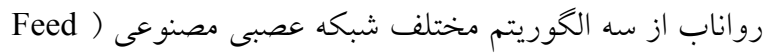
Radial Basis Function ‘Forward Back Propagation و و Generalized Regression Neural Network و ركرسيون خطى جند گانه استفاده كردند. اين شـبيه سـازى جريـان در دو مرحله انجام كرفت. مرحله اول، از دادههـاى بـارش بـا ثأ روز

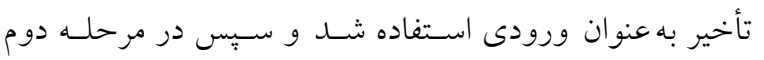

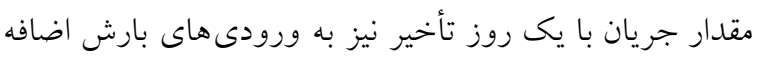

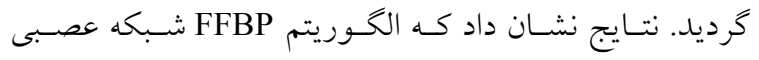

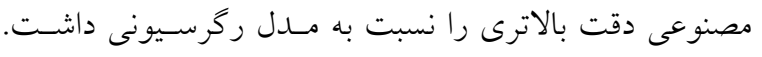

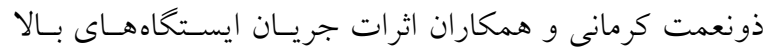

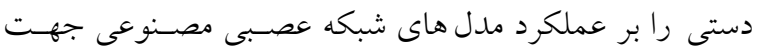

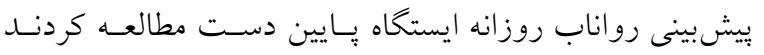

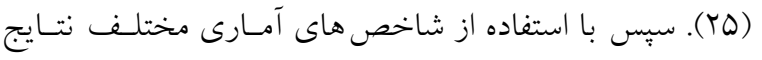
نو اقص دادهها هميشه در تحليل هاى آمارى مشكل ساز بودهانـــ.

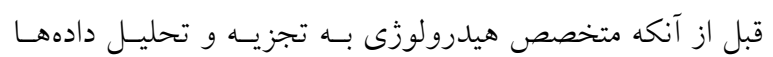

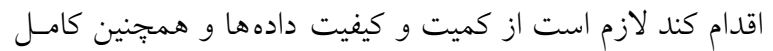
بودن سرى آمارى اطمينان حاصل نمايد. بدون ارزيـابى صسحيح

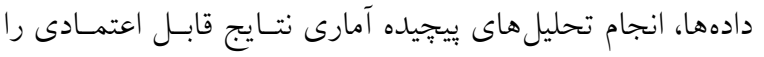

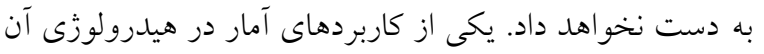

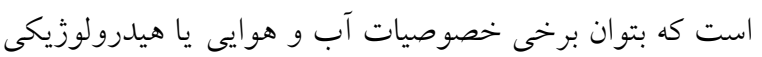

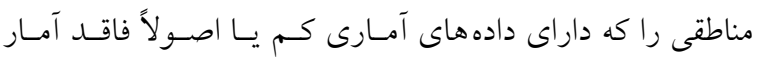

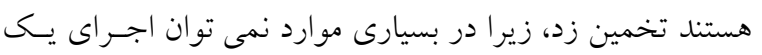

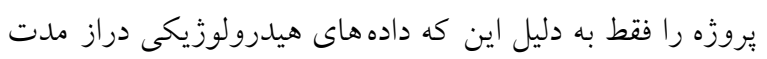

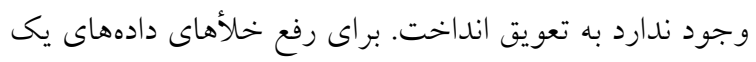

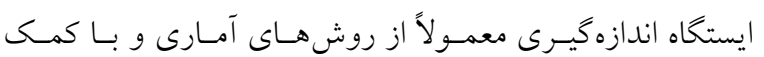

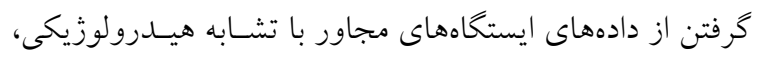

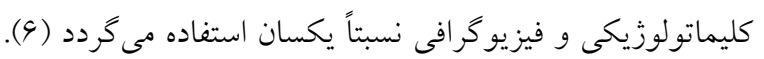

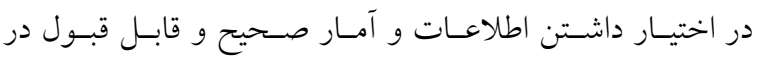

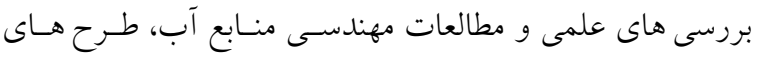

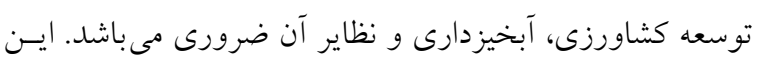

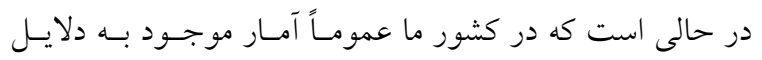

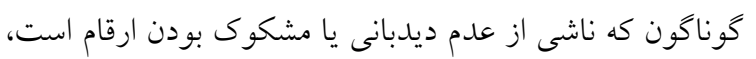

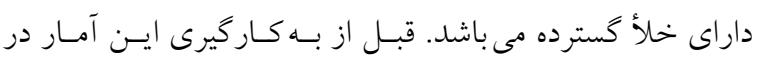

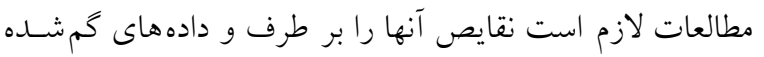
را بازسازى كرد. بنابراين دسترسى به داده هاى كـافى و دقيـق از يك طرف موجب كوتاه تر شدن مدت مطالعات و از طرف ديخر

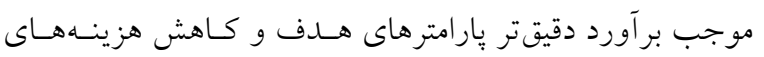
اجرايى و خسارات هاى بعدى ناشى از اجراى طرح ها مى خـردد

دستورانى و همكاران به مقايسه كارايى روشهاى مختلـف جهت بازسازى و تطويل دادههاى هيدرولوزى يرداختنـد (r). در اين تحقيق ترميم نواقص دادهاى دبى ماهانه با استفاده از

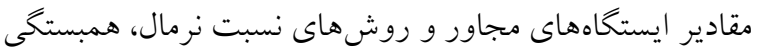
بين ايستخاهها و شبكههاى عصبى مصنوعى انجام شـد. نتـايج 
دادههاى اقليمى در سـه شــايط آب و هــوايى مختلـف ايـــان

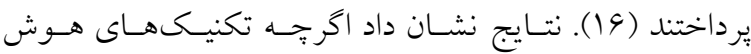

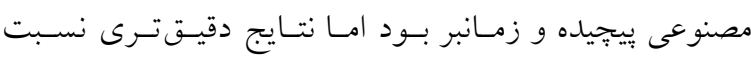

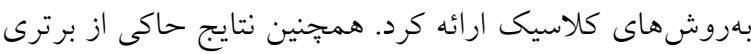

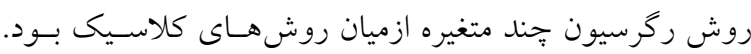
ككبولاك و همكاران فرايند بارش - رواناب يك حوضه دونه آبخيز

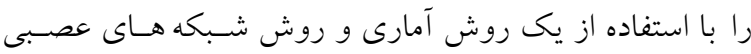

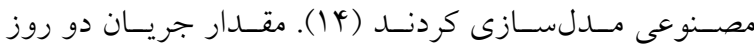
كذشـته

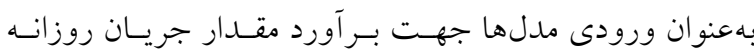

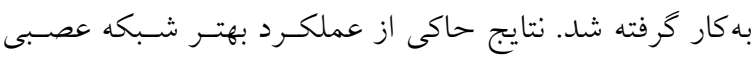
مصنوعى در شبيهسـازى جريـان بـود. نقــى و همكـاران بـهـ

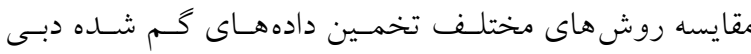

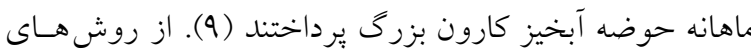

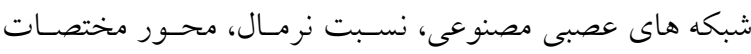

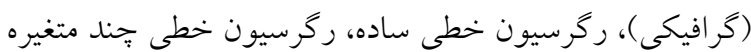

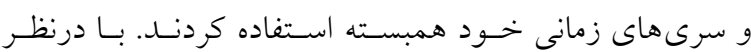

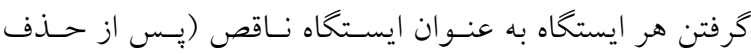

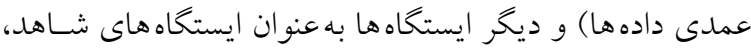

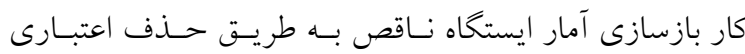
(حذف عمدى) هر يكى از دادهها انجام شد. نتايج نشاندهنــاه برترى روش شبكه هاى عصبى مصنوعى در مقايسـه بـا ديخــ

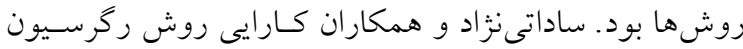
خطى فازى در مقايسه با روشهـاى رخرسيون خطسى سـاده، ركرسيون جند متغيره و روش محور مختصاتى و نسبت نرمـال را براى بازسازى دبى سالانه ايستخاههاى هيدرومترى حوضـهـ

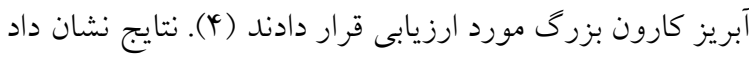
روش ركرسيون خطى ساده بهعنوان روش برتـر در بازسـازى

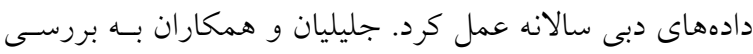
كارايى روش هاى مختلف در بازسازى داده هـاى هيـدرومترى

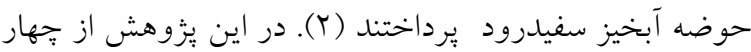

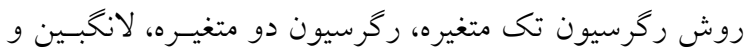

Multiple ) شبكه عصبى مصنوعى و رگرسيون خطى جند (Linear Regression اين تحقيق از شش تركيب مختلف جريان روزانه ينج ايستخاه

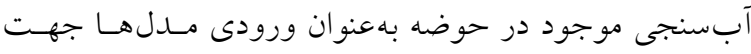

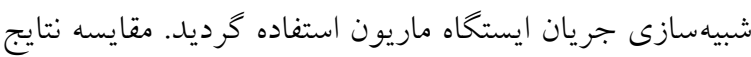
دو روش نشـان داد كـهـ روش شـبكه عصـبى مصــنوعى در

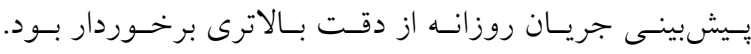

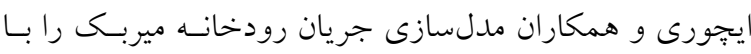

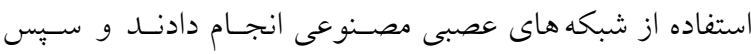

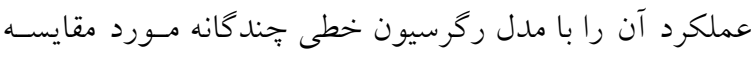

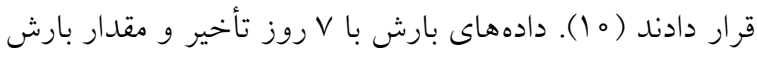

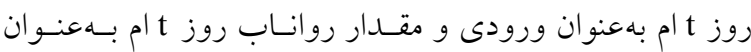

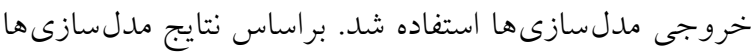

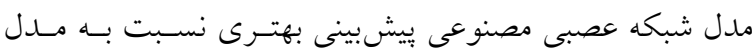

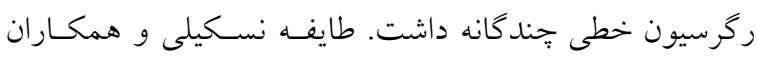
ارزيابى شبيههاى مختلف شبكه عصبى مصنوعى و روشهـاى

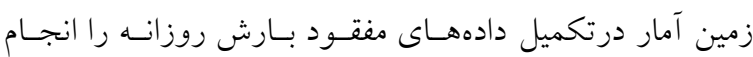

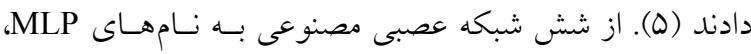

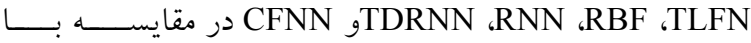

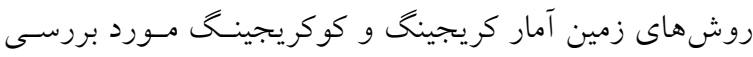

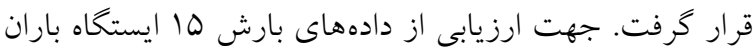
سنجى موجود در حوضه كرخه استفاده شـــ. نتـايج نشـان داد كه مدل MLP در برآورد دادههاى مغقود بارش مؤثرتر از بقيـهـ عمل كرد. كوثرى و قرده از شبكه عصبى مصنوعى و الكوريتم

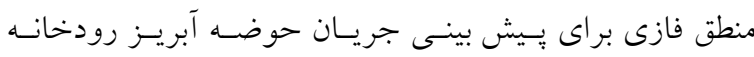

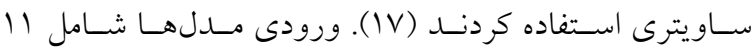
تركيب مختلف شـامل مقــدار روزانـه بـارش، متوسط تبخيـر روزانه، متوسط درجه حرارت روزانه و مقــار جريـان روزانـهـ

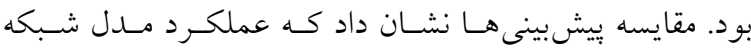

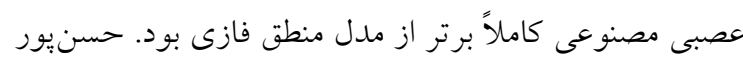

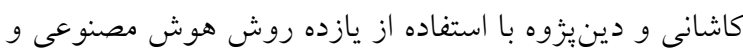
روشهاى آمارى كلاسيك به تعيين مدل مناسب بــــاى بــر آورد 
را مطالعـه كـرد (YI). شـش تركيـب مختلـف دادههـاى سـه

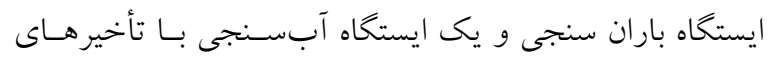

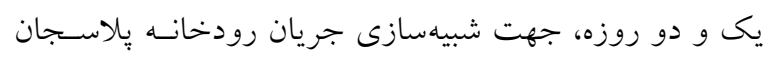

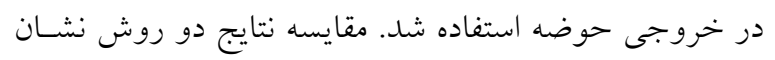

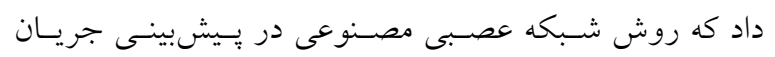

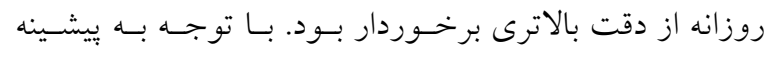

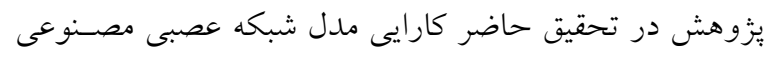

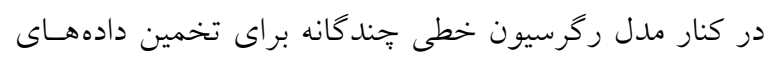

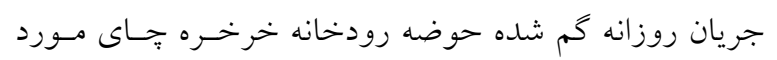

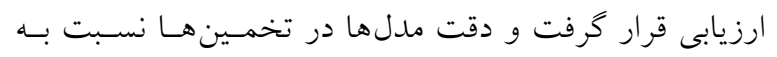

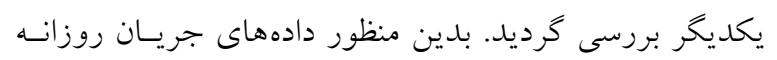

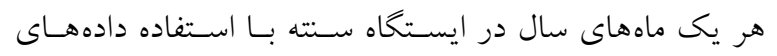
بارش و جريان ايستخاههاى مجاور تخمين زده شد. بـا توجسهـ

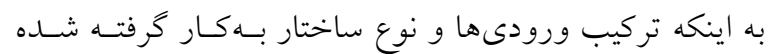

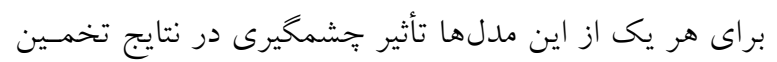

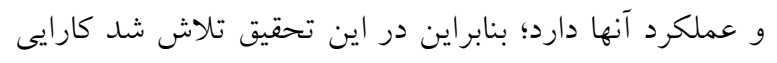

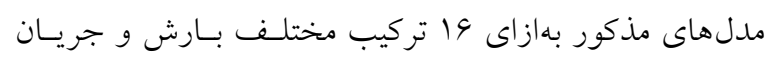

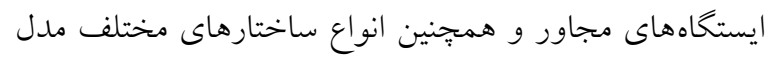

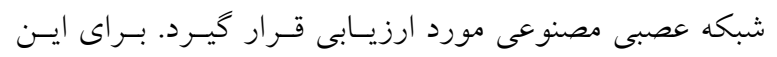

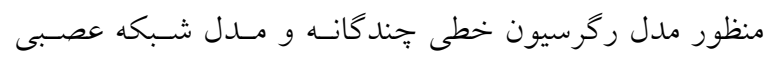

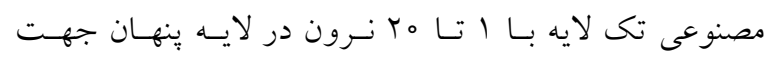

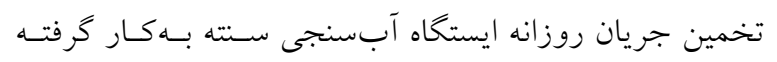

\section{مواد و روشها - - ماد}

\section{دادهها و منطقه مورد مطالعه}

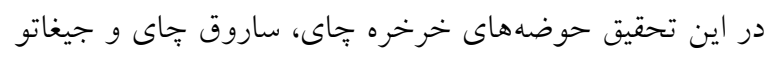

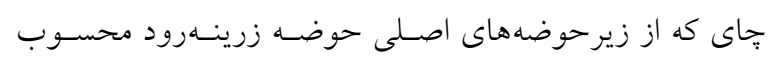

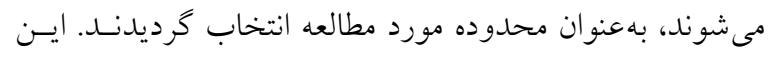

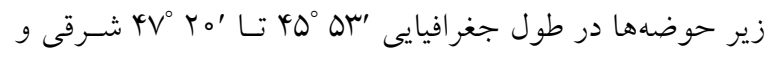

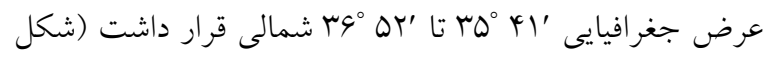

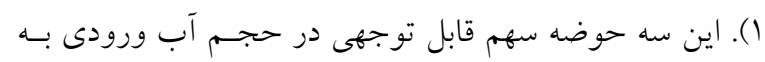

توماس فايرينخ براى بازسازى دادههاى جريان ماهانه، جريـان

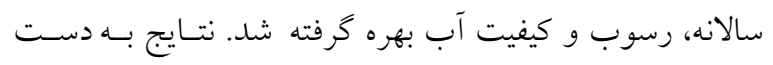

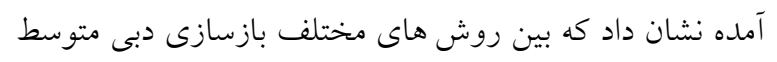

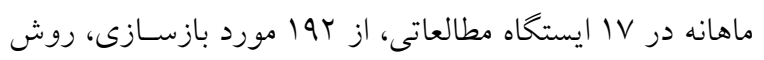

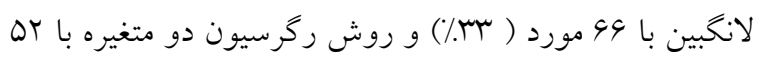

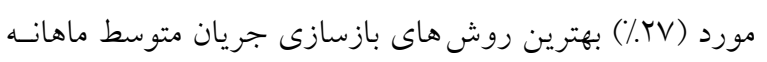

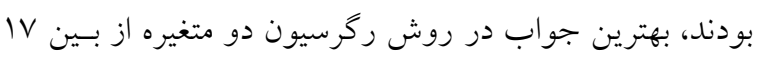

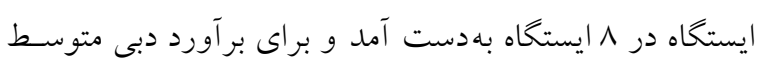

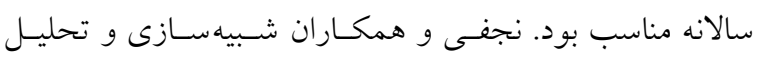

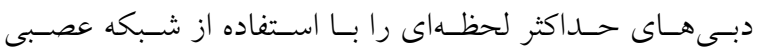

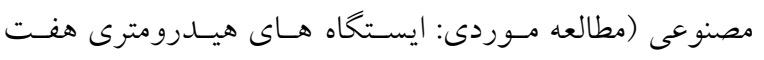

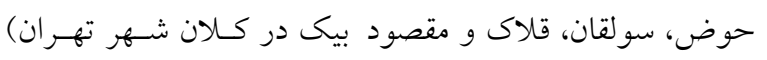

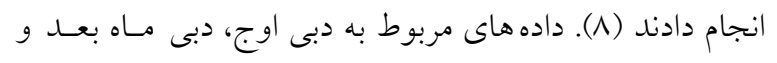

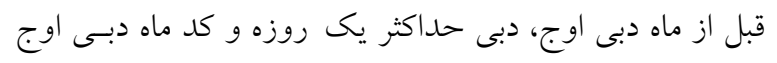

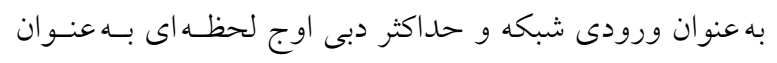

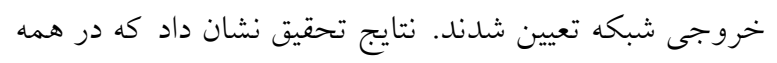

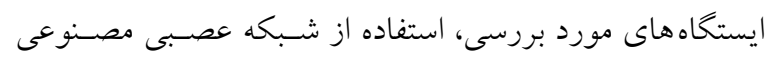

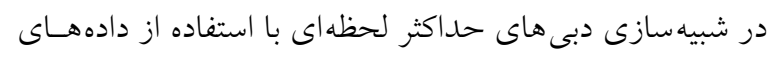

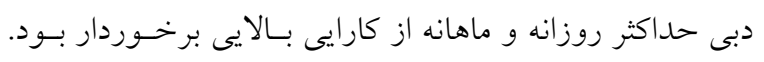

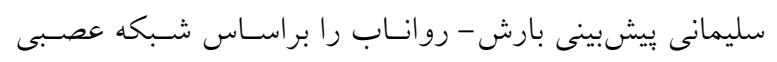

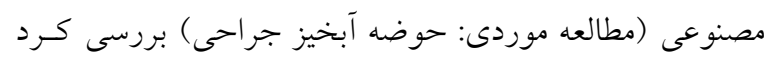

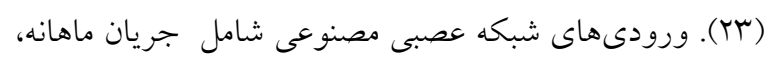

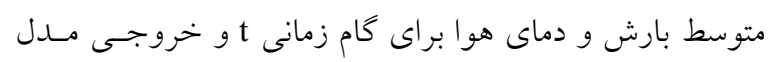

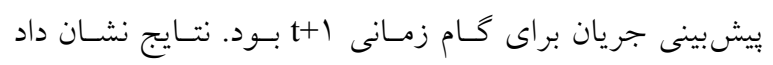

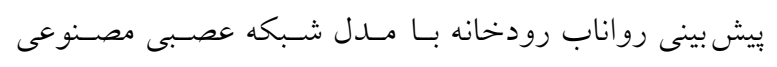

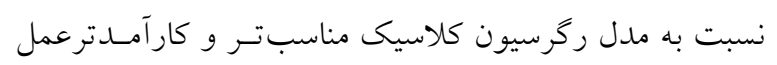

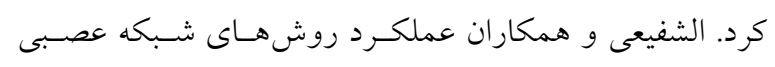

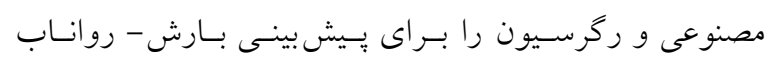

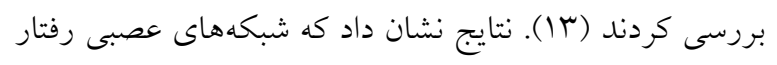

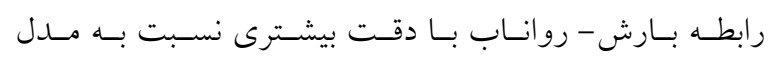

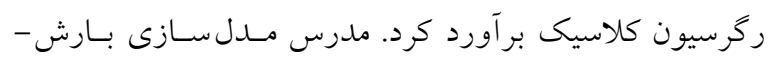

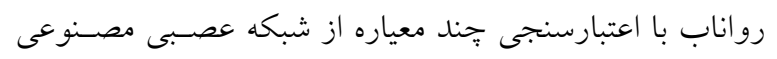




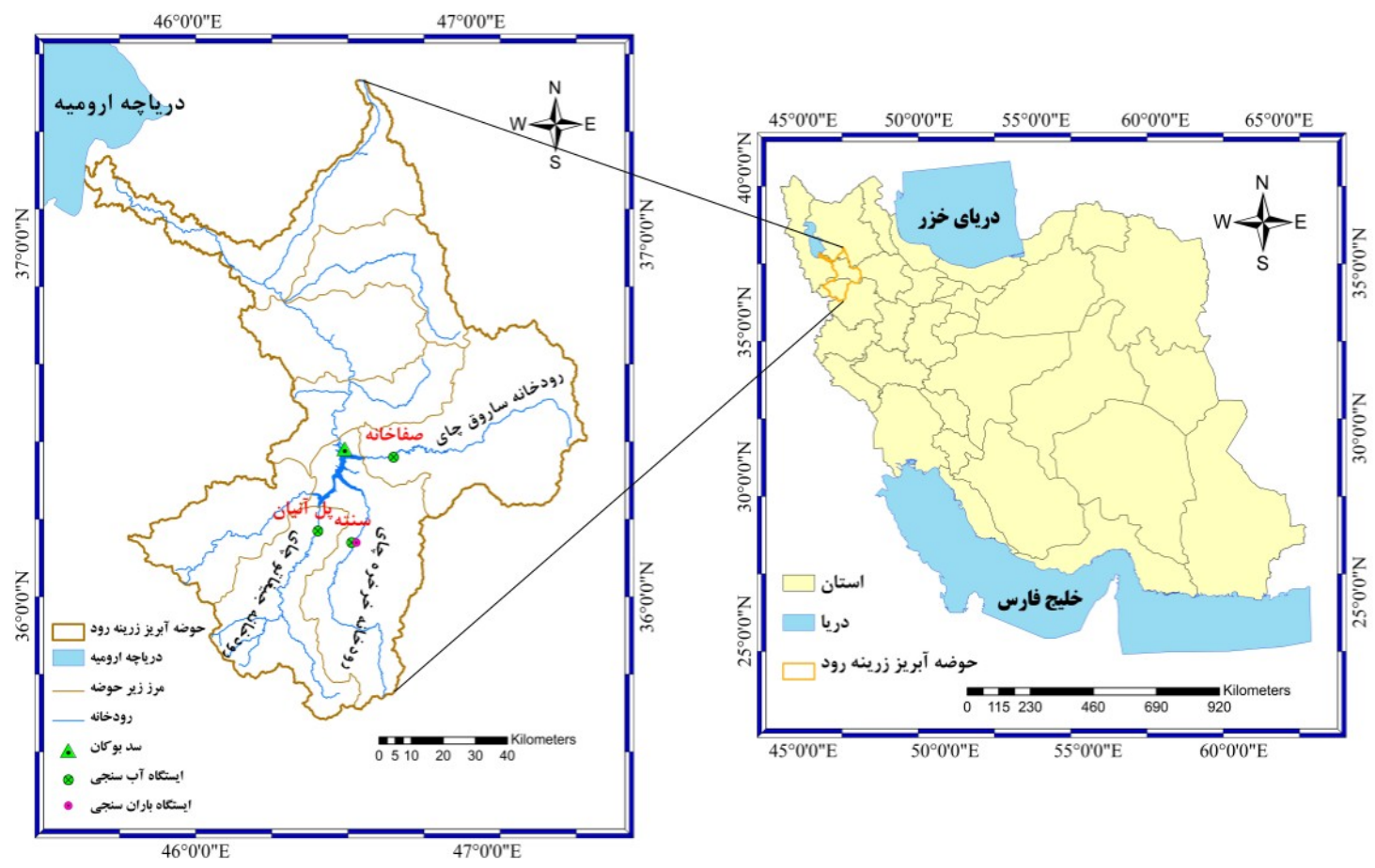

شكل ا. موقعيت حوضه آبريز مورد مطالعه و ايستخاههاى هيدرومترى و باران سنجى

تعيين تعداد ورودى مدلها در اين تحقيق تعداد ورودىها براساس مقدار ضريب همبستخى

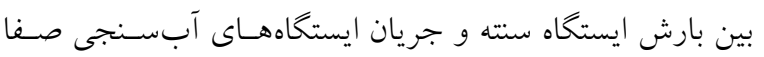

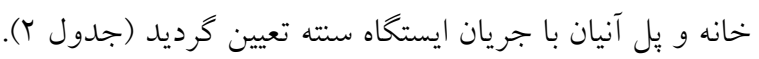
نتايج جدول (Y) نشان داد، همبستكى بين بارش ايستخاه سـتنه

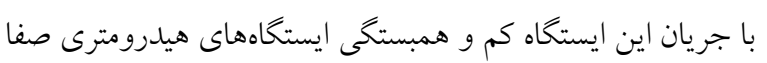

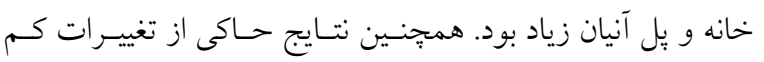

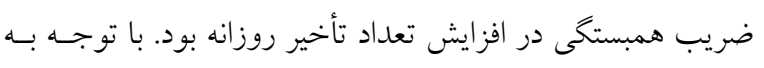
موارد ذكر شده و ساير مطالعات صـورت گرفتـه در زمينـه تـرميم دادهاى گم شده و مدلسازى، تركيـبـهـاى مختلـف وروديىهـا جدول (r) جهت بيشبينى جريان ايستخاه سنته درنظر كرفته شد.

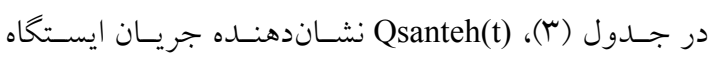

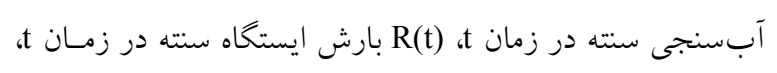
Qs(t-1) و Qه ترتيب جريان ايستخاه آبسنجى صفا خانسه

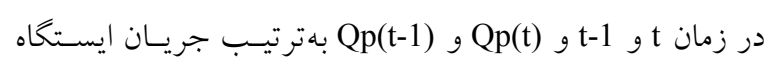
آبسنجى يل آنيان در زمان t و t-1 بود.
سد بوكان و در نتيجه تأمين نيازهاى آبى پيايين دست اين سد

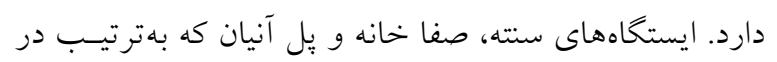
حوضههاى خرخره جاى، ساروق جاى و جيغاتو ¥اى واقع

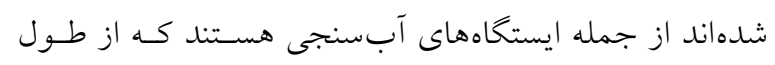
دوره آمارى قابل قبول برخوردار مي باشند. مسـاحت حوضــه

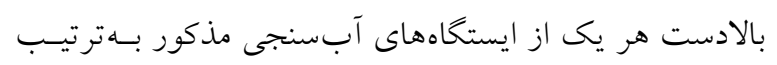

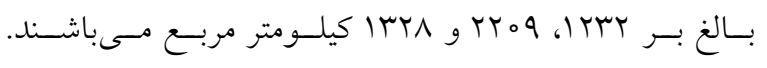
همجينين متوسط بارش سـالانه ايسن حوضسه در حسدود ميلى متر مىباشد. دادهاى مورد استغاده در اين تحقيق شـامل

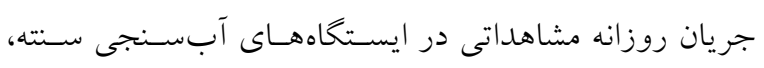

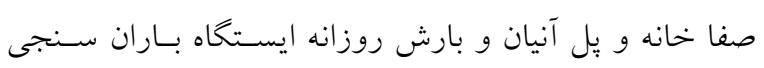

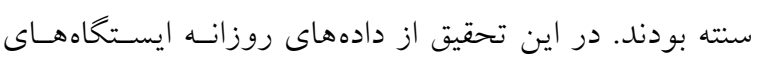

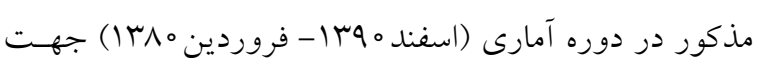
مدلسازى استفاده شد. مشخصات مربوط به دادههاى جريـان

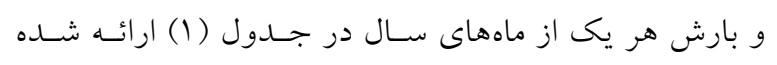
است 


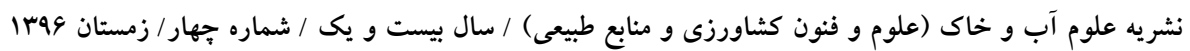

ب

جدول ا. مشخصات آمارى ايستخاههاى آبسنجى و باران سنجى حوضه مورد مطالعه

\begin{tabular}{|c|c|c|c|c|c|c|c|c|c|c|c|c|}
\hline \multicolumn{3}{|c|}{ آبسنجى يل آنيان } & \multicolumn{3}{|c|}{ آبسنجى صفا خانه } & \multicolumn{3}{|c|}{ آبسنجى سنته } & \multicolumn{3}{|c|}{ باران سنجى سنته } & \multirow[b]{2}{*}{ ماه } \\
\hline ave & $\max$ & std & ave & $\max$ & std & ave & $\max$ & Std & ave & $\max$ & Std & \\
\hline$V T / V$ & rVV/。 & $\Delta r / r$ & $Y Y / V$ & $r \| / r$ & TN/I & $\mu$ & $10 Y / \circ$ & $r 9 / 9$ & $r / 0$ & $4 \circ / 0$ & $\Delta / \Delta$ & فروردين \\
\hline $09 / 9$ & YYV/O & $90 / 1$ & $Y Y / D$ & $19 \% / 0$ & $r \mid / 9$ & $r M / Y$ & $1 M / \circ$ & $r I / T$ & $1 / 1$ & $90 / 0$ & $0 / 9$ & ارديبهشت \\
\hline $19 / 0$ & rOI/。 & $\varphi Q / 9$ & $r / v$ & $09 / 9$ & $V / Q$ & $0 / 9$ & $\mathrm{ra/V}$ & $Q / T$ & $\circ / \Gamma$ & $19 / 0$ & $1 / 9$ & خرداد \\
\hline $1 / \pi$ & $10 / 1$ & $1 / 9$ & $0 / 9$ & $\varphi / \varphi$ & $1 / 0$ & $1 / 0$ & $V / 4$ & $1 / 0$ & $0 / 0$ & $9 / 0$ & $\circ / \Gamma$ & تير \\
\hline $0 / T$ & $1 / r$ & $\circ / \mu$ & $\circ / \mu$ & $r / 0$ & $\circ / 4$ & $1 / 9$ & $r V / 4$ & $Q / V$ & $0 / 1$ & $V / \circ$ & $0 / 9$ & مرداد \\
\hline $0 / 1$ & $\circ / 4$ & $0 / 1$ & $0 / r$ & $1 N / \Lambda$ & $1 / \mu$ & $\circ / 1$ & $1 / 4$ & $0 / T$ & $0 / 1$ & $14 \%$ & $0 / 9$ & شهريور \\
\hline $0 / T$ & $Y / 0$ & $\circ / 4$ & $\circ / 0$ & $r \circ / \mu$ & $1 / 4$ & $0 / r$ & $r / 9$ & $0 / 4$ & $0 / T$ & $1 \% / 0$ & $1 / 1$ & مهر \\
\hline$r / 1$ & $110 / 0$ & $10 / 0$ & $T / 1$ & $r \circ / 9$ & $T / 9$ & $T / \varphi$ & $r v / r$ & $4 / 9$ & $1 / 9$ & $4 \circ / 0$ & $Q / T$ & آبان \\
\hline $\mathrm{V} / \mathrm{\circ}$ & $1 T r / 9$ & $I T / r$ & $T / Q$ & $1 \pi / 9$ & $1 / V$ & $r / r$ & $41 / 1$ & $y / 0$ & $1 / 9$ & $99 / 0$ & $9 / T$ & آذزر \\
\hline $11 / \mathrm{V}$ & $|V| N$ & $\mid V / 4$ & $r / 。$ & $9 / 9$ & $1 / r$ & $\varphi / 1$ & $Y V / D$ & $Y / V$ & $1 / 9$ & $49 / 0$ & $\varphi / \Lambda$ & دى \\
\hline$r \mid / 9$ & rrq/。 & $T V / T$ & $4 / 9$ & $Y Y / D$ & $r / \Lambda$ & $V / 9$ & $V \mu / V$ & $10 / 1$ & $r / Q$ & $90 / 0$ & $\mathrm{~V} / \mathrm{0}$ & بهمن \\
\hline$\Delta F / \Lambda$ & $Y \circ V / \circ$ & $00 / 9$ & $11 / \mathrm{V}$ & $V \pi / \Lambda$ & $\mid r / T$ & $r M / 9$ & $r+q / 0$ & $r q / 0$ & $r / 0$ & $\& V / 0$ & $9 / 1$ & اسفند \\
\hline
\end{tabular}

جدول r. ضريب همبستخى بين ورودىها با جريان ايستگاه سنته

\begin{tabular}{|c|c|c|c|}
\hline جريان يل آنيان & جريان صفا خانه & بارش سنته & تأخير روزانه \\
\hline $0 / 94$ & $\circ / V 1$ & $\circ / \Lambda$ & $\circ$ \\
\hline $0 / 91$ & $0 / 99$ & $0 / 11$ & 1 \\
\hline$\circ / Q V$ & $0 / 91$ & $\circ / \circ \wedge$ & r \\
\hline$\circ / \Delta \Delta$ & $0 / 91$ & $\circ / \circ \wedge$ & $r$ \\
\hline - $/ Q Y$ & $0 / 91$ & $\circ / \circ \wedge$ & r \\
\hline سه/ & $0 / 99$ & $\circ / \circ \wedge$ & 0 \\
\hline.$/ 01$ & $0 / 99$ & $0 / 09$ & 4 \\
\hline$\circ / 0 \circ$ & $0 / 91$ & $\circ / \circ \wedge$ & V \\
\hline $0 / 49$ & $0 / 91$ & $0 / 09$ & $\wedge$ \\
\hline $0 / 4 q$ & $0 / 91$ & $0 / 0 \wedge$ & 9 \\
\hline$\circ / 4 \wedge$ & $0 / 99$ & $0 / 09$ & 10 \\
\hline
\end{tabular}

و كسترش آن براساس قواعــ زيـر بنـا نهـاده شــده اسـت. 1-

شبكه عصبى مصنوعى با آموزش لونبر - ماركوارت

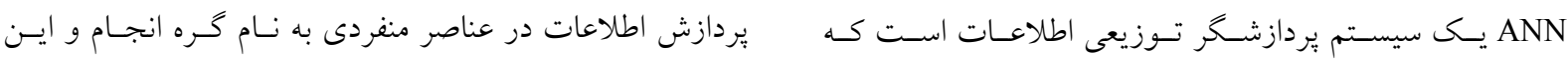

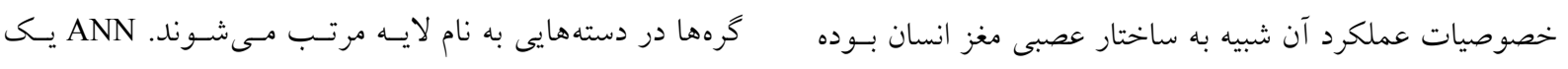




\begin{tabular}{|c|c|c|}
\hline \multicolumn{3}{|c|}{ جدول r. تركيبهاى مختلف بارش و جريان جهت بيشبينى جريان ايستخاه آبسنجى سنته } \\
\hline 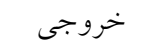 & تركيب ورودى & شماره تركيب ورودى \\
\hline Qsanteh $(\mathrm{t})$ & $\mathrm{Qs}(\mathrm{t})-\mathrm{R}(\mathrm{t})$ & 1 \\
\hline Qsanteh $(\mathrm{t})$ & $\mathrm{Qp}(\mathrm{t})-\mathrm{R}(\mathrm{t})$ & r \\
\hline Qsanteh $(\mathrm{t})$ & $\mathrm{Qs}(\mathrm{t}-1)-\mathrm{Qs}(\mathrm{t})-\mathrm{R}(\mathrm{t})$ & r \\
\hline Qsanteh $(\mathrm{t})$ & $\mathrm{Qp}(\mathrm{t}-1), \mathrm{Qp}(\mathrm{t}), \mathrm{R}(\mathrm{t})$ & r \\
\hline Qsanteh $(\mathrm{t})$ & $\mathrm{Qp}(\mathrm{t}), \mathrm{Qs}(\mathrm{t}), \mathrm{R}(\mathrm{t})$ & 0 \\
\hline Qsanteh $(\mathrm{t})$ & $\mathrm{Qp}(\mathrm{t}), \mathrm{Qs}(\mathrm{t}-1), \mathrm{Qs}(\mathrm{t}), \mathrm{R}(\mathrm{t})$ & 9 \\
\hline Qsanteh $(\mathrm{t})$ & $\mathrm{Qp}(\mathrm{t}), \mathrm{Qp}(\mathrm{t}-1), \mathrm{Qs}(\mathrm{t}), \mathrm{R}(\mathrm{t})$ & V \\
\hline Qsanteh $(\mathrm{t})$ & $\mathrm{Qp}(\mathrm{t}), \mathrm{Qp}(\mathrm{t}-1), \mathrm{Qs}(\mathrm{t}-1), \mathrm{Qs}(\mathrm{t}), \mathrm{R}(\mathrm{t})$ & $\wedge$ \\
\hline Qsanteh $(\mathrm{t})$ & $\mathrm{Qp}(\mathrm{t}), \mathrm{Qs}(\mathrm{t}-1), \mathrm{R}(\mathrm{t})$ & 9 \\
\hline Qsanteh $(\mathrm{t})$ & $\mathrm{Qp}(\mathrm{t}-1), \mathrm{Qs}(\mathrm{t}), \mathrm{R}(\mathrm{t})$ & 10 \\
\hline Qsanteh $(\mathrm{t})$ & $\mathrm{Qp}(\mathrm{t}), \mathrm{Qs}(\mathrm{t})$ & 11 \\
\hline Qsanteh $(\mathrm{t})$ & $\mathrm{Qp}(\mathrm{t}), \mathrm{Qp}(\mathrm{t}-1)$ & ir \\
\hline Qsanteh $(\mathrm{t})$ & Qs(t-1), Qs(t) & ir \\
\hline Qsanteh $(\mathrm{t})$ & $\mathrm{Qs}(\mathrm{t}-2), \mathrm{Qs}(\mathrm{t}-1), \mathrm{Qs}(\mathrm{t}), \mathrm{R}(\mathrm{t}) \mathrm{Qp}(\mathrm{t}-1)$, & 14 \\
\hline Qsanteh $(\mathrm{t})$ & Qs(t-2), Qs(t-1), Qs(t), R(t) Qp(t-1), Qs(t-3), & 10 \\
\hline Qsanteh $(\mathrm{t})$ & $\mathrm{Qp}(\mathrm{t}-1), \mathrm{Qs}(\mathrm{t}-3), \mathrm{Qs}(\mathrm{t}-2), \mathrm{Qs}(\mathrm{t}-1), \mathrm{R}(\mathrm{t}) \mathrm{Qp}(\mathrm{t}-2)$, & 19 \\
\hline
\end{tabular}

خروجى بستخى به نوع مسئله دارد (تعـداد نـرون لايسه اول برابر تعداد ورودى ها و تعداد نرون لايه خروجى برابر تعـداد

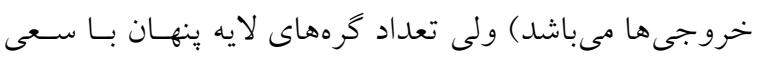
خطا بهدست مى آيد. در شبكههاى بيشرو، كرههـايى وجــود

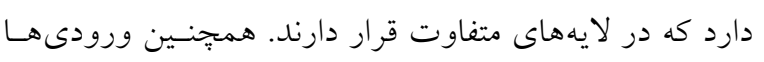
در لايه ورودى شبكه نمايش داده شـده و عمـل تحريـى از ورودى به سمت خروجى شبكه شروع مسى شـود (11). لازم

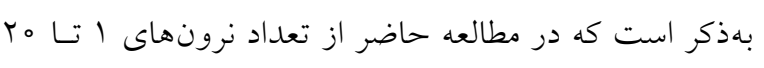
براى لايه ينهان شبكه استفاده كرديد تا از ايسن طريـق بتـوان

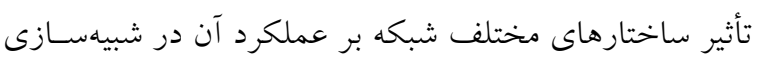

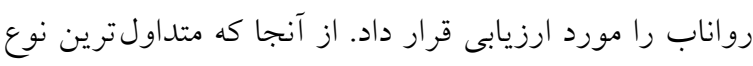
توابع محرك، تابع تانزانت سيخموئيد مسىباشــ بنـابراين، در

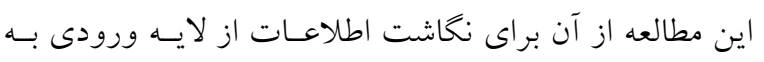

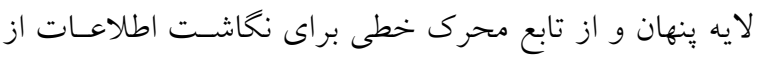
لايه ينهان به لايه خروجى استفاده كرديد.
سيستم بردازشـحر تـوزيعى اطلاعـات اسـت كـه خصوصسيات عملكرد آن شبيه به ساختار عصبى مغز انسان بـوده و كسـترش

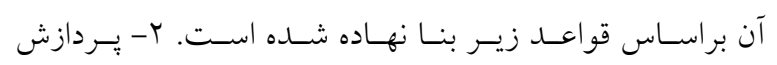
اطلاعات در عناصر منفردى به نام گره انجام و ايسن خـــهــا در دستههايى به نام لايه مرتب مىشوند. ب- سيخنالها بين خـرهــا

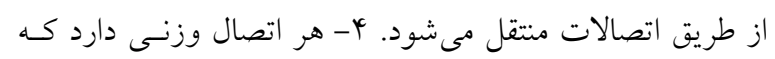

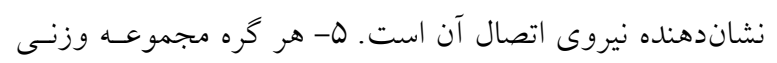

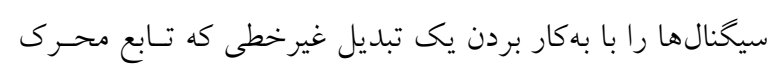
ناميده مىشود به سيخنال خروجى تبديل مى كند (11 و بأب).

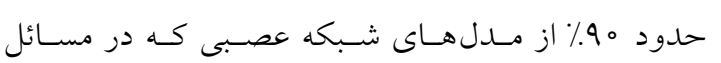

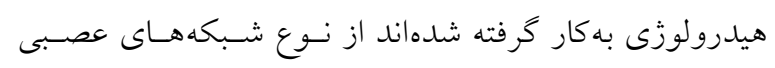

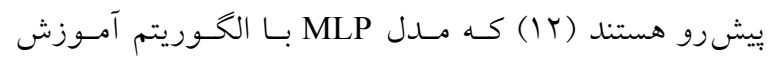
لونبرك- ماركوارت از مهمترين آنها بهشمار مىرود. معمارى معمول اين شبكه متشكل از سه بخش لايه ورودىى، ينهـان و خروجى مىباشد. تعداد نرونهاى موجود در لايسه ورودى و 
$\left(\begin{array}{c}y_{1} \\ y_{r} \\ \vdots \\ y_{n}\end{array}\right)=$

$$
\begin{aligned}
& \left(\begin{array}{ccccc}
1 & x_{11} & x_{1 r} & \ldots & x_{1 k} \\
1 & x_{Y 1} & x_{Y r} & \cdots & x_{Y k} \\
\vdots & \vdots & \vdots & & \vdots \\
1 & x_{n 1} & x_{n Y} & \cdots & x_{n k}
\end{array}\right) \\
& +\left(\begin{array}{c}
\beta \\
\beta_{j} \\
\vdots \\
\beta_{k}
\end{array}\right)+\left(\begin{array}{c}
\varepsilon_{1} \\
\varepsilon_{r} \\
\vdots \\
\varepsilon_{n}
\end{array}\right)
\end{aligned}
$$$$
\text { معادله فوق را مىتوان بهصورت ساده زير نوشت: }
$$

$\mathrm{Y}=\mathrm{X} \beta+\varepsilon$

كه در آن X ماتريس به ابعاد (k+1) n× بردارهاى Y و ع ع بـه

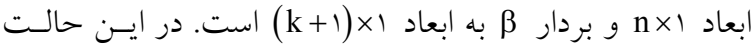

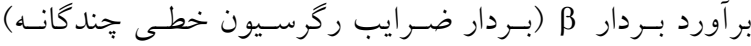
بلمروش حداقل مربعات خطا، از رابطه زير بهدست مى آيد: $\hat{\beta}=\left(X^{\prime} X^{\prime}\right)^{-1} \cdot X^{\prime} Y$

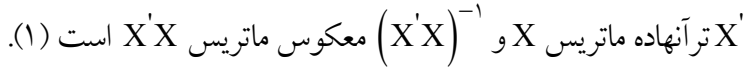

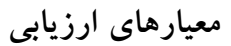

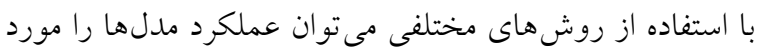

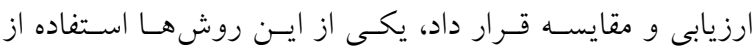
معيارهاى ارزيابى مىباشد. از جمله معيارهاى ارزيابى ڤير كاربرد در علوم مهندسى آب، ضرايب، ريشه ميانخين مربعـات خطسا و

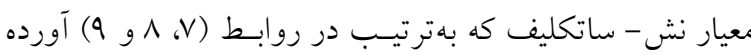
شدند. دقيقترين مدل با توجه به اين معيارها، مدلى خواهد بـود

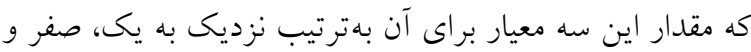

يكى باشد.

$$
\begin{aligned}
& \mathrm{CC}=\sqrt{\frac{\left(\sum_{\mathrm{i}=1}^{\mathrm{N}}\left(\mathrm{x}_{\mathrm{i}}-\overline{\mathrm{x}}\right)\left(\mathrm{y}_{\mathrm{i}}-\overline{\mathrm{y}}\right)\right)^{r}}{\sum_{\mathrm{i}=1}^{\mathrm{N}}\left(\mathrm{x}_{\mathrm{i}}-\overline{\mathrm{x}}\right)^{r} \sum_{\mathrm{i}=1}^{\mathrm{N}}\left(\mathrm{y}_{\mathrm{i}}-\overline{\mathrm{y}}\right)^{r}}} \\
& \mathrm{RMSE}=\sqrt{\frac{1}{\mathrm{~N}} \sum_{\mathrm{i}=1}^{\mathrm{N}}\left(\mathrm{x}_{\mathrm{i}}-\mathrm{y}_{\mathrm{i}}\right)^{r}} \\
& \mathrm{NS}=1-\frac{\sum_{\mathrm{i}=1}^{\mathrm{N}}\left(\mathrm{x}_{\mathrm{i}}-\mathrm{y}_{\mathrm{i}}\right)^{r}}{\sum_{\mathrm{i}=1}^{\mathrm{N}}\left(\mathrm{x}_{\mathrm{i}}-\overline{\mathrm{x}}\right)^{r}}
\end{aligned}
$$

ركرسيون خطى جند كانه

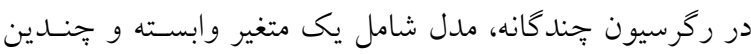

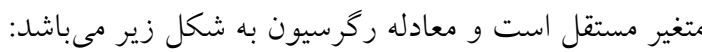
$\mathrm{y}=\beta_{\circ}+\beta_{1} \mathrm{x}_{1}+\ldots+\beta_{\mathrm{k}} \mathrm{x}_{\mathrm{k}}+\varepsilon$

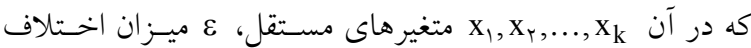

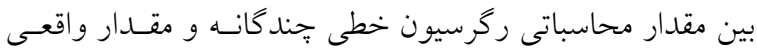

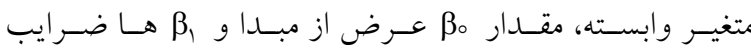

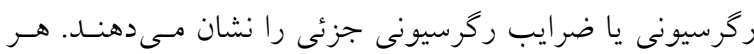

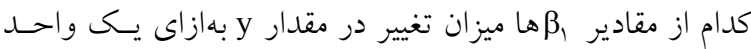
تغيير در مقدار x متناظر را، وقتى كـه سـاير متغيرهـاى مستستل

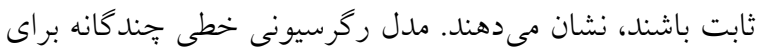

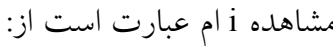
$y_{i}=\beta_{0}+\beta_{1} x_{i 1}+\ldots+\beta_{k} x_{i k}+\varepsilon_{i} \quad i=1, r_{,} \ldots, n$

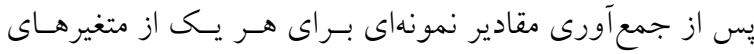

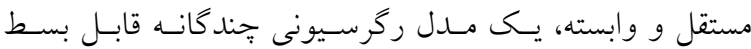

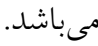
بهور كلى، اخر جندين متغير مستقل در تغيير يذيرى متغيـر

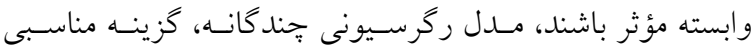

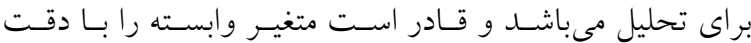

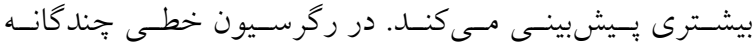
فرضهاى زير بايد برقرار باشند:

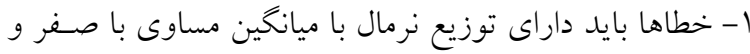
واريـانس ثابـت باشــ: يعنسى ناهمبسته باشند. r- يكى رابطه خطى بـين متغيـر وابستهـ و

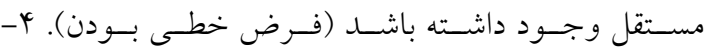
متغير هاى مستقل با همديخر همبستكى خطى نداشته باشـند

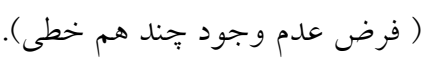

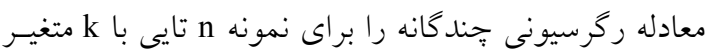

$$
\text { مستقل مىتوان بهصورت زير نوشت: }
$$

$\mathrm{y}_{1}=\beta_{\circ}+\beta_{1} \mathrm{x}_{11}+\ldots+\beta_{\mathrm{k}} \mathrm{x}_{1 \mathrm{k}}+\varepsilon_{1}$

$\mathrm{y}_{\Upsilon}=\beta_{\circ}+\beta_{\Upsilon} \mathrm{x}_{\Upsilon Y}+\ldots+\beta_{\mathrm{k}} \mathrm{x}_{\Upsilon \mathrm{k}}+\varepsilon_{\Upsilon}$

$\mathrm{y}_{\mathrm{n}}=\beta_{\circ}+\beta_{1} \mathrm{x}_{\mathrm{n})}+\ldots+\beta_{\mathrm{k}} \mathrm{x}_{\mathrm{nk}}+\varepsilon_{\mathrm{n}}$

اين n معادله را مىتوان بهصورت ماتريسى زير نوشت: 
ارزيابى مدلهاى شبكه عصبى مصنوعى و رگرسيون خطى جندگانه در تخمين ...

جدول أ. ارزيابى عملكرد مدل شبكه عصبى مصنوعى در تخمين جريان روزانه ايستخاه سنته در هر يك از ماهاى سال

\begin{tabular}{|c|c|c|c|c|c|c|c|c|c|c|}
\hline \multicolumn{4}{|c|}{ آَمارههاى ارزيابى عملكرد (صحتسنجى) } & \multicolumn{4}{|c|}{ آمارههاى ارزيابى عملكرد (آموزش) } & \multirow{2}{*}{ تركيب منتخب } & \multirow{2}{*}{ تر كيب منتخب } & \multirow[b]{2}{*}{ ماه } \\
\hline $\mathrm{t}$ & NS & $\begin{array}{c}\text { RMSE } \\
\left(\mathrm{m}^{\top} / \mathrm{s}\right)\end{array}$ & $\mathrm{CC}$ & $\mathrm{t}$ & NS & $\begin{array}{l}\text { RMSE } \\
\left(\mathrm{m}^{r} / \mathrm{s}\right)\end{array}$ & $\mathrm{CC}$ & & & \\
\hline $19 / 41$ &.$/ 00$ & IN/AV & $\circ / V \mu$ & $11 / 99$ & $0 / 91$ & $N / 91$ & O/AT & 14 & V & فروردين \\
\hline $19 / 4 \Lambda$ & $\circ / \mu$ & $19 / 94$ & $0 / 94$ & $99 / 00$ & $\circ / \mathrm{VI}$ & N/GY & $\circ / \wedge \Delta$ & IV & 11 & 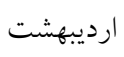 \\
\hline $14 / 99$ & $\circ / \mu r$ & $\varphi / T \wedge$ & $0 / 9 Y$ & $\wedge V / 99$ & $0 / 9 \mathrm{~V}$ & $1 \circ / \Gamma_{0}$ & O/AT & r & $\Delta$ & خ خرداد \\
\hline $1 / / 4$ & $0 / 49$ & $\circ / \mathrm{r}$ & $\circ / V_{0}$ & $101 / 99$ & $\circ / \sqrt{ } 4$ & $\Lambda / 9 \wedge$ & $\circ / \wedge V$ & Ir & 0 & تير \\
\hline r/Y & O/OY & $0 / 9 \mathrm{~V}$ & ./Ir & $V V / q \Lambda$ & $0 / 94$ & $10 / 91$ & $\circ / V q$ & ir & 1 & 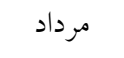 \\
\hline$\Delta / 9 \Lambda$ & $-0 / 09$ & $\circ / \Lambda$ & $\circ / 49$ & $\wedge \varphi / 0{ }^{\prime}$ & $0 / 9 \mathrm{~V}$ & $10 / T Q$ & o/Ar & ir & ir & 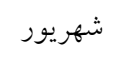 \\
\hline I/TV & $-0 / 09$ & o/ kr & $\circ / \wedge$ & $\vee 9 / 90$ & $0 / 94$ & $10 / 99$ & $\circ / \Lambda \circ$ & V & IT & مهر \\
\hline rr/r。 & $\circ / V Q$ & $r / T \circ$ & ०/AV & $\mid$ & $\circ / \Lambda r$ & V/Tr & $0 / 91$ & ir & $\wedge$ & آبان \\
\hline Ml/4。 & $\circ / V r$ & $r / 09$ & ०/AV & $10 V / 91$ & o/v9 & N/VG & o/AV & 11 & $\wedge$ & آذر \\
\hline TN/T & .199 & T/9。 & o/AK & $1 \circ V / r V$ & $\circ / V 4$ & $\Lambda / \vee \wedge$ & ०/AV & $\wedge$ & 9 & دى \\
\hline$M T / T V$ & $\circ / V G$ & D/TY & $\circ / \mathrm{AV}$ & $110 / \Lambda \mathrm{F}$ & $\circ / \mathrm{VV}$ & $\Lambda / \uparrow \wedge$ & $\circ / \Lambda$ & $r$ & $\wedge$ & بهمن \\
\hline$r Q / \Lambda Q$ & $.19 \mathrm{~V}$ & $19 / 09$ & O/AY & $110 / 19$ & $\circ / \mathrm{V}$ & V/TG & $\circ / \Lambda$ & $\wedge$ & 9 & اسفند \\
\hline
\end{tabular}

مراحل بيشبينى در هر يك از مدلها در تحقيـق حاضـر جهـت هـيشبينسى جريسان روزانـه ايستـاه

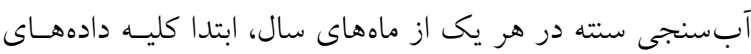

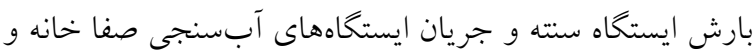

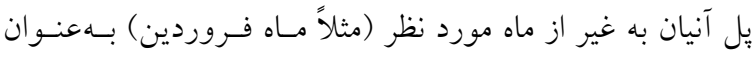

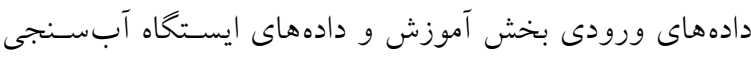

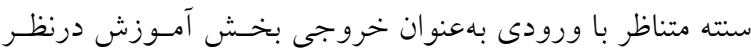

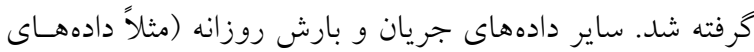

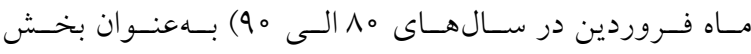

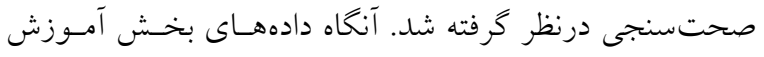

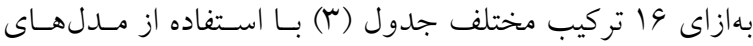
شبكه عصبى مصنوعى و رگرسـيون خطى جنــ متغيسره مـورد

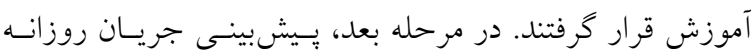

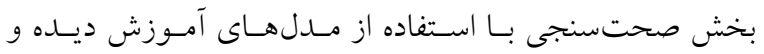
بهازاى ورودىهاى مربوط به بخش صحتسنجى انجام گرفـت.

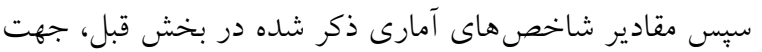

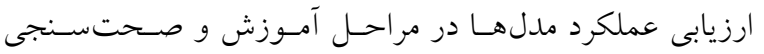

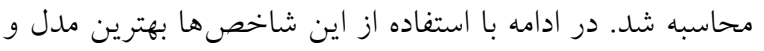

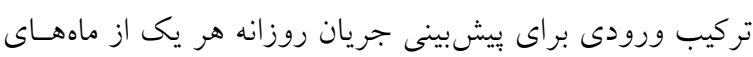

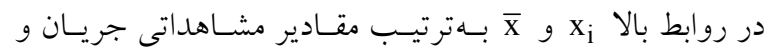

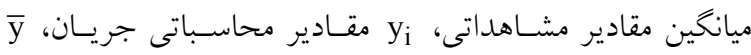

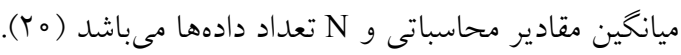

$$
\text { آزمون معنى دارى ضريب همبستخى }
$$

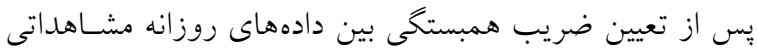

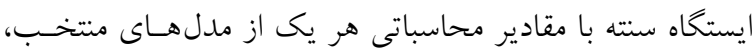
معنى دارى ضريب همبستخى هر يك از مدلهاى منتخب توسط

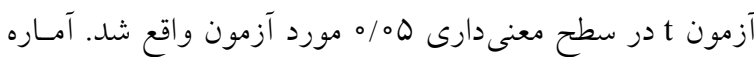

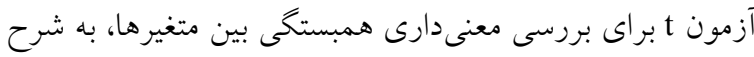

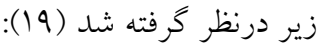
$\mathrm{t}=\frac{\mathrm{r} \cdot \sqrt{\mathrm{n-r}}}{\sqrt{1-\mathrm{r}^{r}}}$

كه در آن n تعداد دادهها و r ضريب همبستخى بـهدسـت آمــده

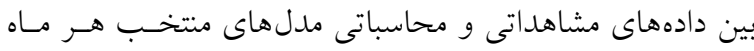
مى باشد كه در جدولهاى (\&) و (Q) نشان داده شده است. اخـر قدر مطلق آماره t محاسبه شده بيشتر از مقدار t جدول (جـدول

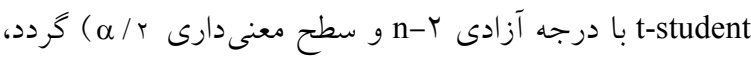

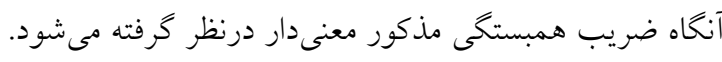




\begin{tabular}{|c|c|c|c|c|c|c|c|c|c|c|}
\hline \multicolumn{11}{|c|}{ جدول ه. ارزيابى عملكرد مدل رگرسيون خطى جندگانه در تخمين جريان روزانه ايستخاه سنته در هر يك از ماههاى سال } \\
\hline \multicolumn{4}{|c|}{ آمارههاى ارزيابى عملكرد (صحتسنجى) } & \multicolumn{4}{|c|}{ 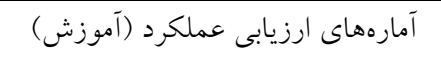 } & \multirow{2}{*}{ تر كيب منتخب } & \multirow{2}{*}{ تركيب منتخبـ } & \multirow{2}{*}{ ماه } \\
\hline $\mathrm{t}$ & NS & $\begin{array}{l}\text { RMSE } \\
\left(\mathrm{m}^{3} / \mathrm{s}\right)\end{array}$ & $\mathrm{CC}$ & $\mathrm{t}$ & NS & $\begin{array}{l}\text { RMSE } \\
\left(\mathrm{m}^{3} / \mathrm{s}\right)\end{array}$ & $\mathrm{CC}$ & & & \\
\hline $14 / 14$ & $0 / Y \Lambda$ & $r Y / D I$ & $0 / 91$ & $9 r / 94$ & $\circ / \Delta r$ & $9 / \wedge 9$ & $\circ / V r$ & $\wedge$ & $\wedge$ & فروردين \\
\hline $10 / V Y$ & $-0 / 01$ & TI/Tr & $\circ / 0 \circ$ & GATr & $\circ / \Delta r$ & $11 / 0 x^{c}$ & $\circ / N r$ & Ir & ir & ارديبهشت \\
\hline $\mid y / 94$ & $-0 / 0 \wedge$ & $\Delta / T V$ & $0 / 9 Y$ & $41 / T_{0}$ & $\circ / 0 \circ$ & $I T / O V$ & $\circ / V_{1}$ & 1 & 1 & خرداد \\
\hline $19 / \mu \mathrm{V}$ & $-Y / I V$ & $1 / \mathrm{V} 9$ & $\circ / V Y$ & $99 / 44$ & $\circ / 00$ & $11 / 99$ & $\circ / V^{4}$ & $\wedge$ & $\wedge$ & تير \\
\hline r/Vq & $\circ / \circ$ & $\Delta / V_{0}$ & $0 / 10$ & $9 V / T I$ &.$/ Q F$ & $11 / A V$ & $\circ / V^{r}$ & 9 & 9 & مرداد \\
\hline $11 / r_{0}$ & $-199 / 94$ & $r / r I$ & - /QT & $99 / \pi 1$ &.$/ Q T^{r}$ & $11 / 91$ & $\circ / V^{r}$ & $\wedge$ & $\wedge$ & شهريور \\
\hline $0 / 01$ & $-r \circ / r V$ & r/To & $\circ / \circ$ & $99 / 40$ &.$/ Q F$ & $11 / 99$ & $\circ / Y^{4}$ & $\wedge$ & $\wedge$ & مهر \\
\hline$r V / 9 \Lambda$ & - $/ \Delta T$ & $r / 19$ & o/NK & $99 / 14$ & $\circ / \Delta \Delta$ & $11 / 90$ & $\circ / Y^{4}$ & $\wedge$ & $\wedge$ & آبان \\
\hline r.\%。 & - /Qr & $r / M$ & ०/A9 & 99109 &.$/ Q F$ & $\mid r / 00$ & $\circ / V^{r}$ & 11 & 11 & آذر \\
\hline rG/MN & $\circ / \Delta \Lambda$ & $r / Y Y$ & O/AY & $G V / Y I$ &.$/ \Delta 0$ & $11 / 94$ &.$/ V^{4}$ & $\wedge$ & $\wedge$ & دى \\
\hline 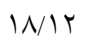 & $\circ / \Lambda$ & $r / 90$ & $\circ / \mathrm{VI}$ & $91 / 99$ &.$/ 01$ & $I T / r V$ & $\circ / V_{1}$ & 1 & 1 & بهمن \\
\hline r./ & $0 / \Gamma \wedge$ & TY/M & $\circ / V Q$ & $4 V / 19$ & $0 / \Gamma \wedge$ & $11 / 19$ & $0 / 91$ & r & r & اسفند \\
\hline
\end{tabular}
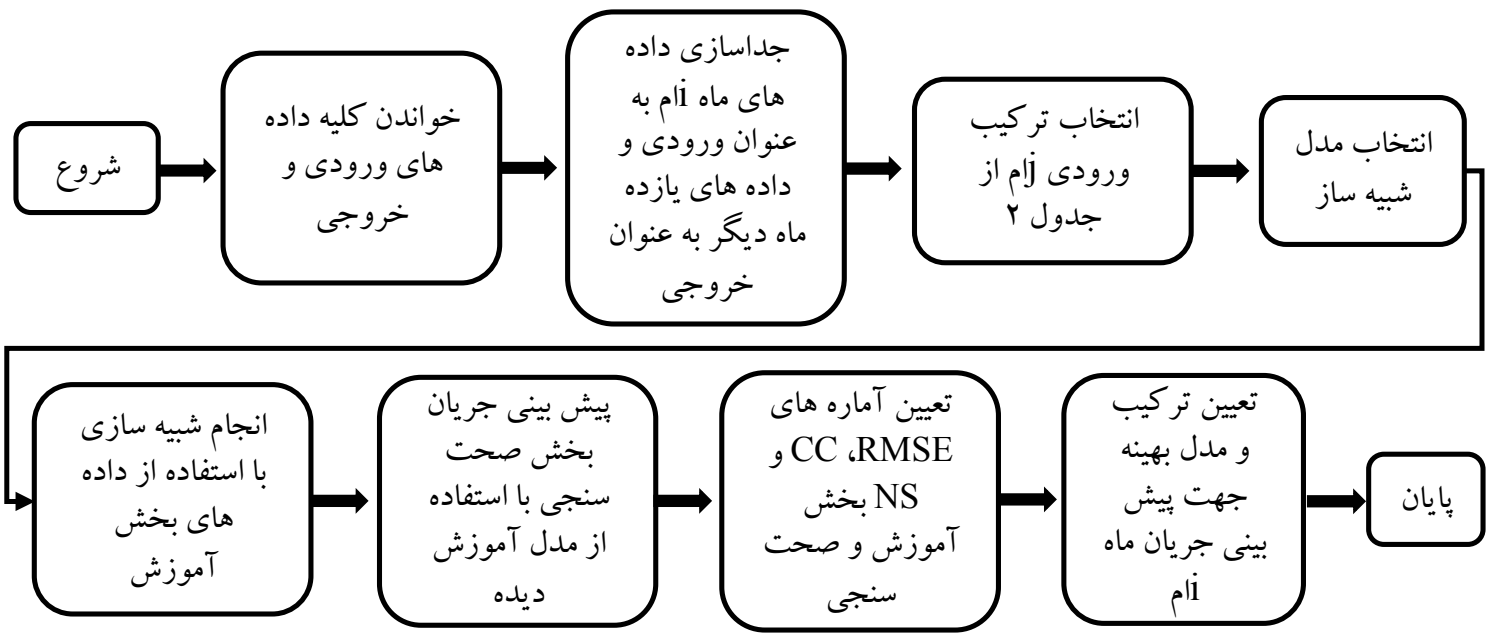

شكل r. مراحل انجام شبيهسازى با استفاده از مدلهاى مورد استفاده

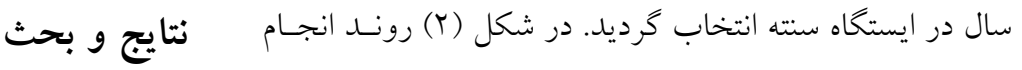

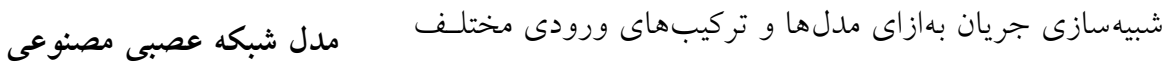

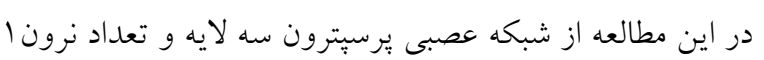
تا مب جهت بيش بينى جريان روزانه ايستخاه سنته در ماه استفاده

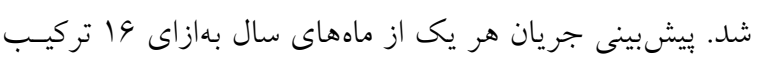
نشان داده شده است.

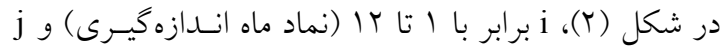
شماره تركيب ورودى جدول (r) است. 


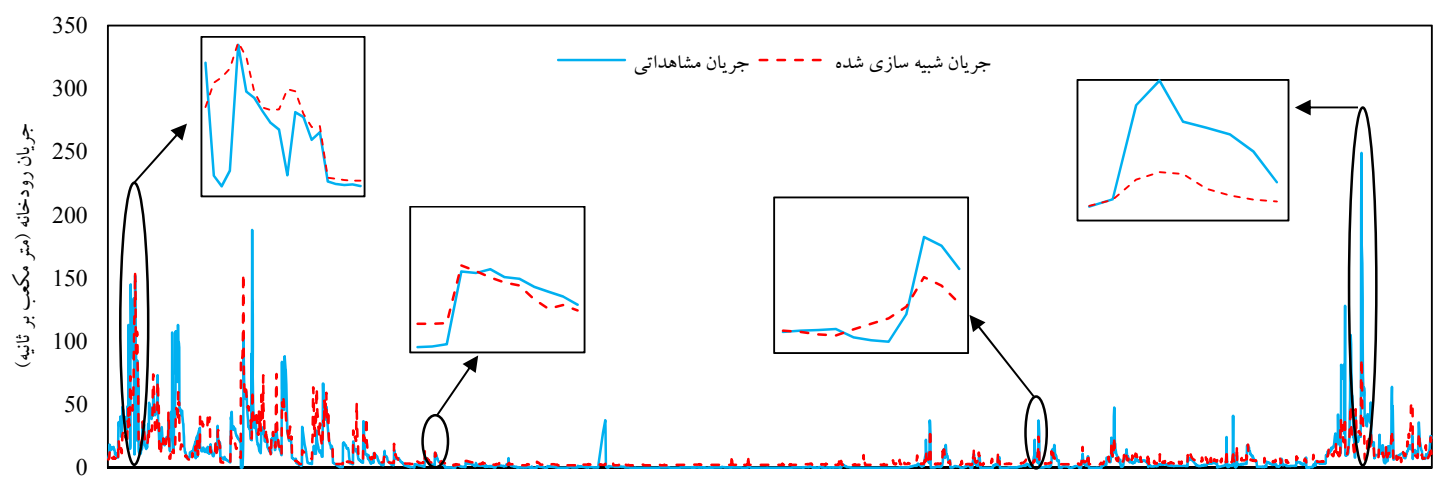

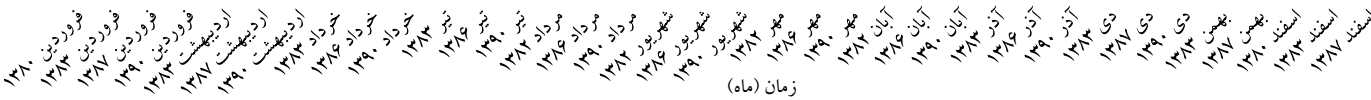

شكل r. مقادير دبى جريان روزانه مشاهداتى و بيشينى شده دوره صحتسنجى با مدلهاى منتخب در ايستخاه آبسنجى سنته

لازم بهذكر است كه VQ درصد از حجم كل جريسان ورودى

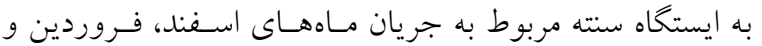
ارديبهشت بود؛ البته با افزودن درصد جريان مـاههـاى بهمـن و و خرداد اين مقدار به M درصد رسيد. بنابر اين مـلىلى كسه بتوانــا

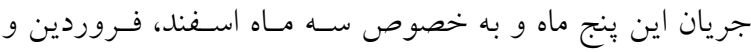
ارديبهشت را با دقـت بيشـتر و خطـاى كمتـرى تخمسين بزنــا، مى تواند بهعنوان مـدل برتسر جهـت يـيشبينسى جريـان روزانـه ايستخاه سته درنظر كرفته شود. با توجه به اينكه مقدار جدول آماره t-student بـا درجسه آزادى

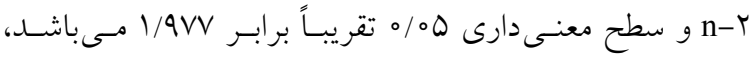

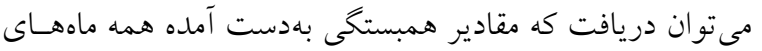

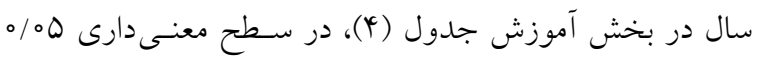

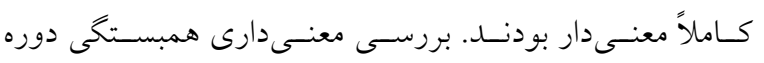

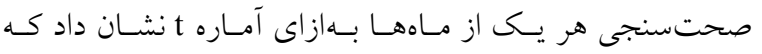
ضريب همبستخى دوره صحت صنجى همه ماهها بغير از ماه مهر

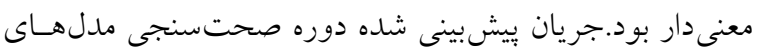

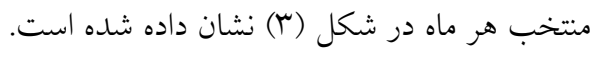

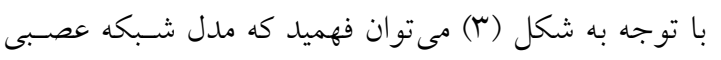

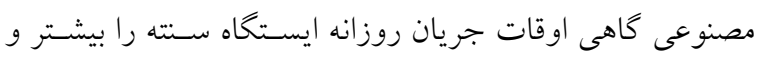

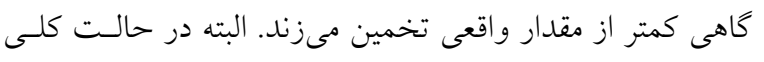

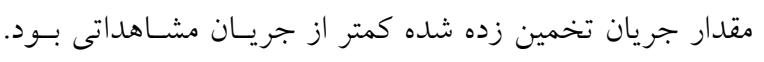

ارائه شده در جــدول (r) انجــام شـــ. بـا توجـهـ بـه معيارهـاى ارزيابى، تركيبى كه بهترين نتيجه ييشبينى را در هر ماه بهدست

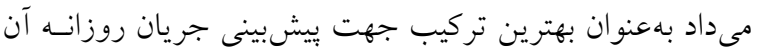

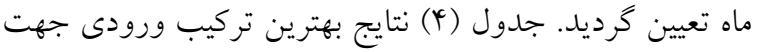
يبشبينى جريان هر يك از ماههاى سال را نشان مىدهد.

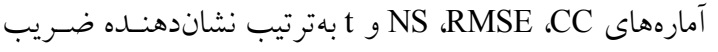
همبستخى، مجذور ميانخين مربعات خطا، شاخص نش - ساتكليف و آماره t-student محاسباتى است. توجه: براى ديدن فـرم تركيـب مربـ ورودى باتوجه به شماره آن به جدول (r) مراجعه فرماييد.

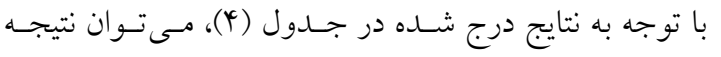
كرفت كه مدل شبكه عصبى مصنوعى مسى توانــ مقــادير جريـان

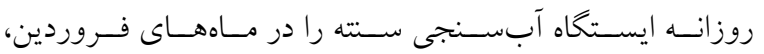

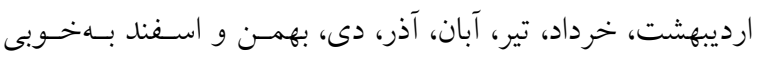

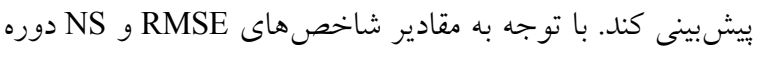

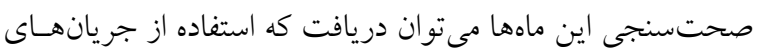

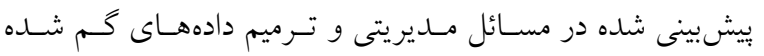

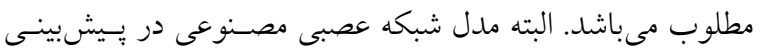

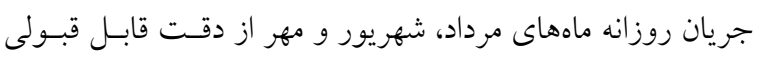

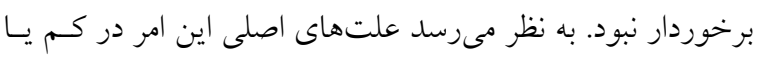

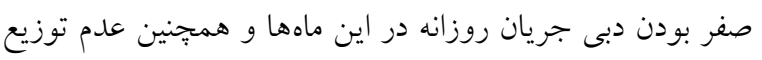
برابر بارشها در كل سطح حوضه آبريز مىباشند. 
صفا خانه (mr/s) در روز جارى، R(t) بـارش روزانـه ايستخاه سنته (mm/day) در روز جارى به ميلى متر مى باشد.

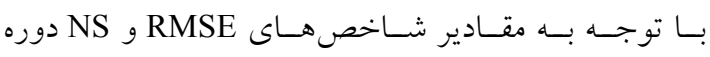

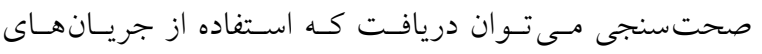

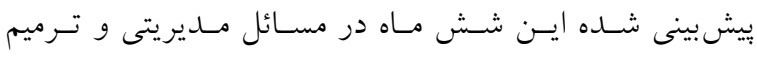

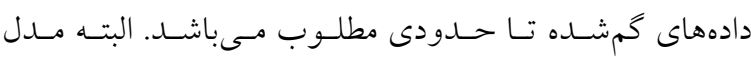
ركرسيون خطى جندكانه در بيشبينى جريان روزانـه مـاههـاى

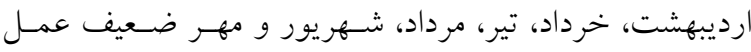

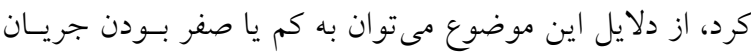

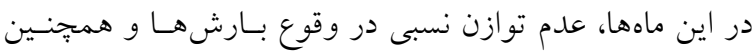

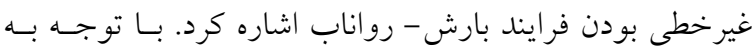

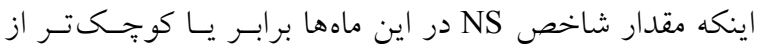

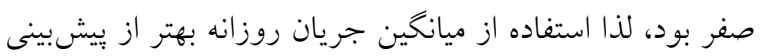

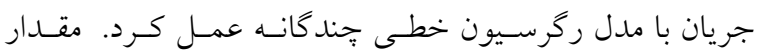

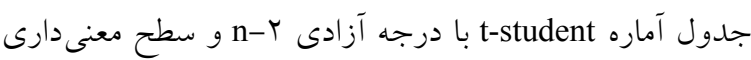

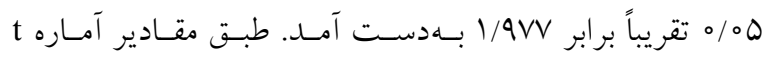

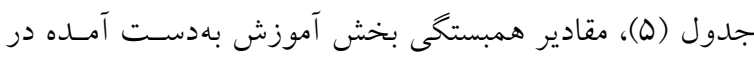

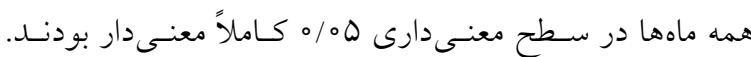

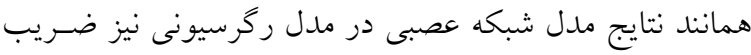

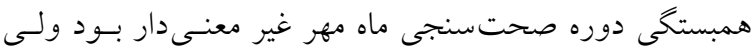

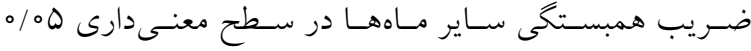

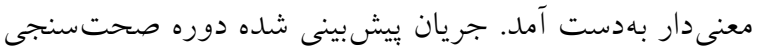

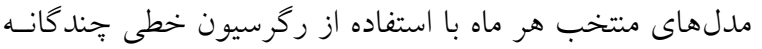
در شكل (Y) نشان داده شده است.

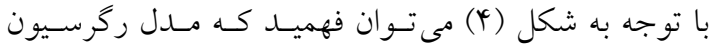
خطى جندگًانه نيز مانند مدل شبكه عصبى، كاهى اوقات جريان را بيشتر و كاهى كمتر از مقدار واقعى تخمين مىزنسـ. البتـه در حالت كلى، مقدار جريان تخمين زده شده كمتر از مقـدار نظيـر جريان مشاهداتى بود و مقدار عددى ميانخين از كسر كردن دبى لمعين

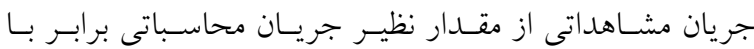
( جندكانه در تخمين مقادير حداكثر نيز (در برخى مواقـع) بسـيار
ميـانخين اخستلاف مقــادير بـهدسـت آمــده از مــل بـا جريـان

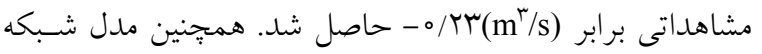
عصبى مصنوعى در تخمين مقادير حداكثر نيز در برخسى مواقع إنع

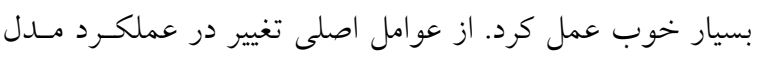

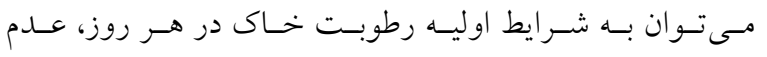

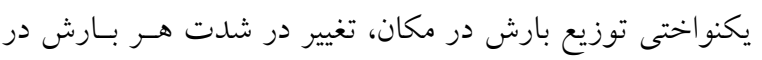
يكى منطقه از حوضه اشاره كرد.

\section{مدل رگر سيون خطى هند مًانه} بيشبينى جريان هر يك از ماههاى سال بهازاى 19 تركيب ارائسه

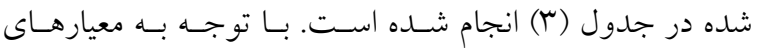
ارزيابى، تركيبى كه بهترين نتيجه بيشبينى را در هر ماه بهدست

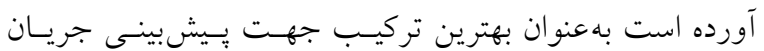

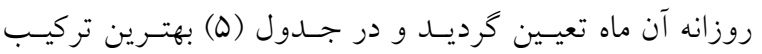
ورودى مشخص شده است. جدول (ه) نتايج ارزيابى عملكـرد

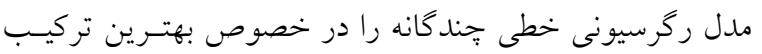
ورودى جهت ويش بينى جريان هر يكى از مـاههـاى سـال نشـان

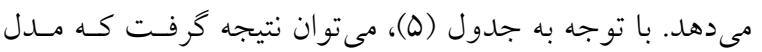

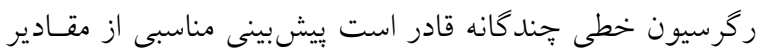

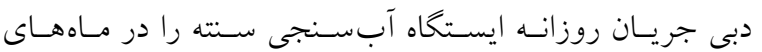

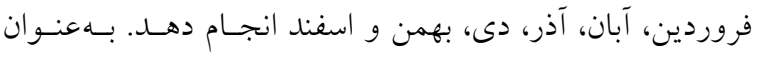

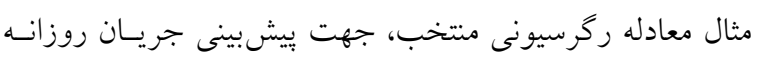

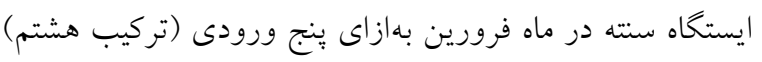

$$
\text { بهورت زير مئاهد }
$$

$$
\begin{aligned}
& \mathrm{Q}_{\text {santeh }}(\mathrm{t})=\circ / r Q * \mathrm{Qp}(\mathrm{t})+\circ / \mathrm{r} * \mathrm{Qp}(\mathrm{t}-1) \\
& +\circ / \circ \mathrm{V}^{*} \mathrm{Qs}(\mathrm{t}-1)+\circ / .4^{*} \mathrm{Qs}(\mathrm{t}) \\
& +\circ / r r^{*} \mathrm{R}(\mathrm{t})+\mathrm{l} / \mathrm{r}
\end{aligned}
$$

كه در آن Q دبsteh

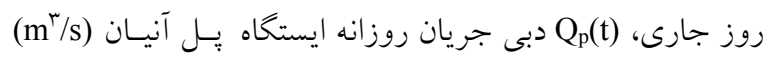

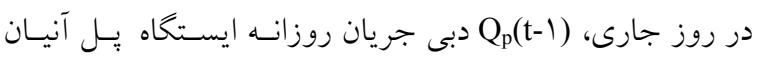
(m²r/s)

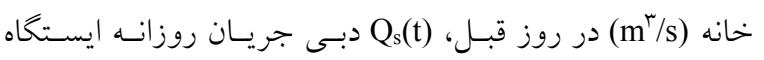




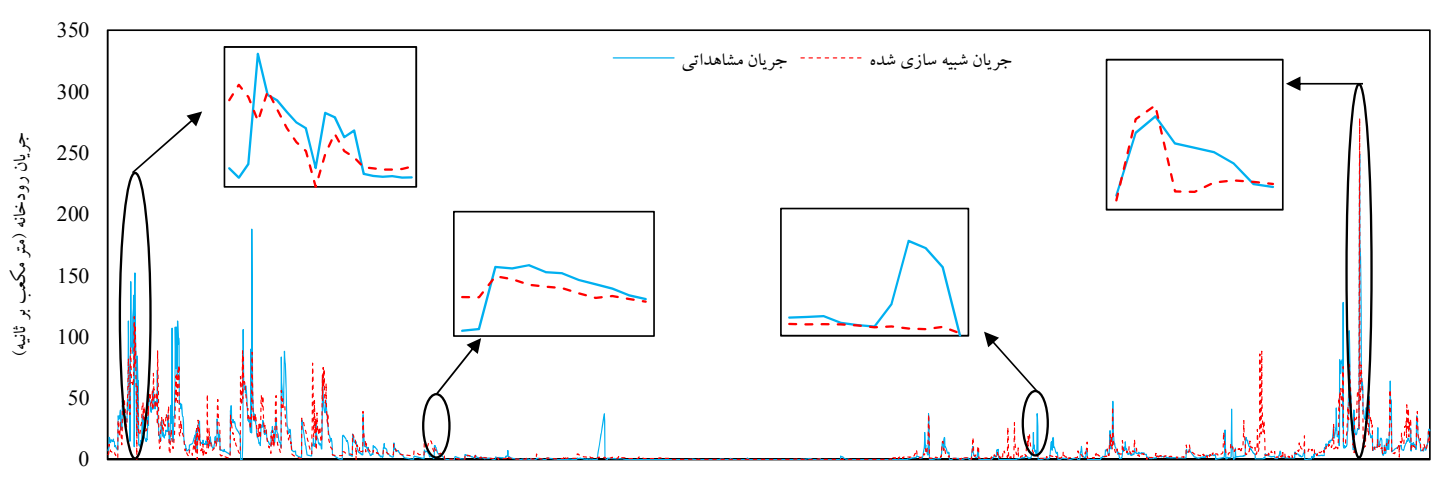

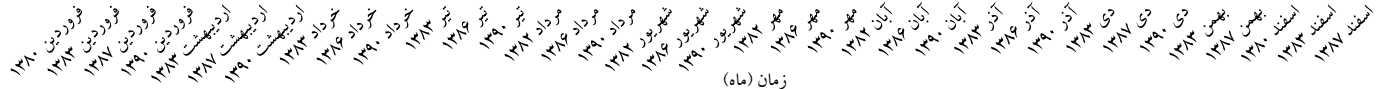

شكل ץ. نمودار دبى جريان روزانه مشاهداتى و بيشبينى شده دوره صحتسنجى مدلهاى منتخب در ايستخاه آبسنجى سنته

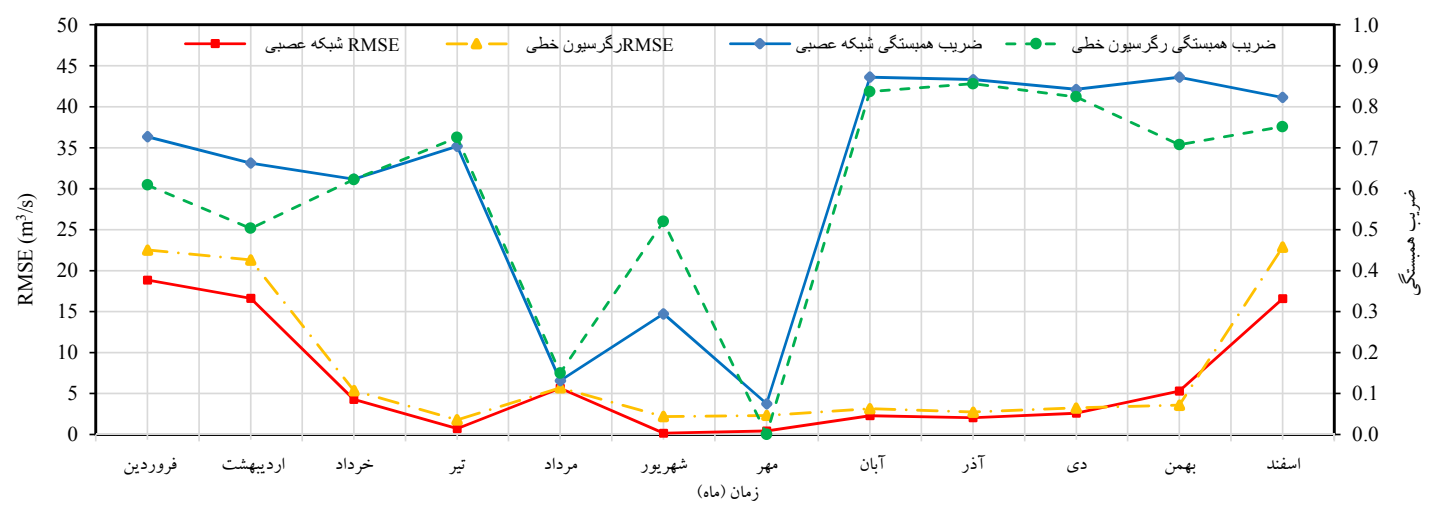

شكل ه. مقايسه عملكرد مدلهاى مورد استفاده با ارائه نمودار مقادير ضريب همبستخى و RMSE جريان روزانه بيشبينى شده در هر ماه در ايستخاه آبسنجى سنته

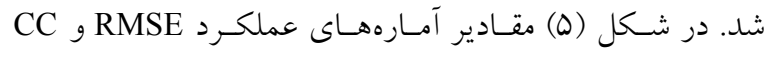
تركيبهاى منتخب ييشبينى جريان هر يـك از مـاههـا در دوره

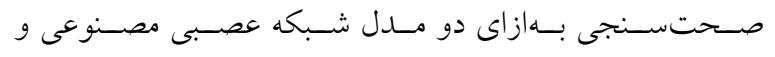
رخرسيون خطى جند گانه نشان داده شده است.

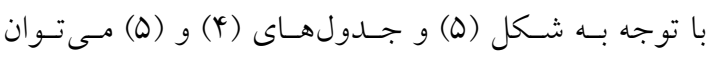

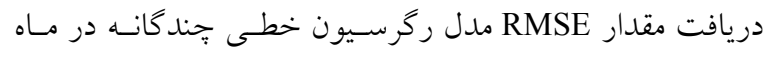

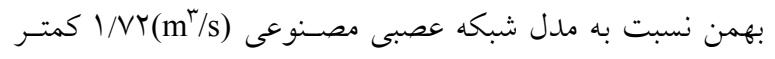

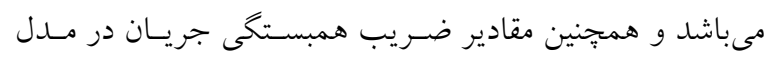

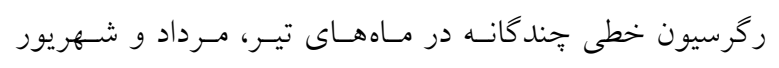

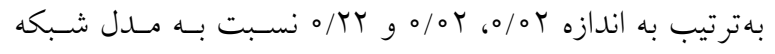

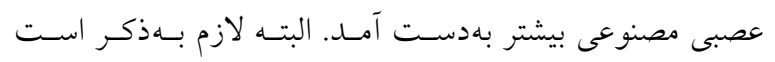

خوب عمـل نمـود. از عوامـل اصـلى تغييـر در عملكـــد مــدل

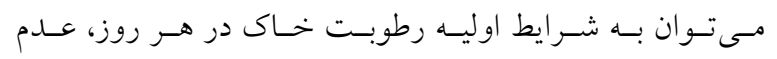
يكنواختى توزيع بارش، تغيير در شدت هـر بــارش و... در هـر يك از زير حوضهها اشاره كرد.

مقايسه عملكرد مدلهاى شبكه عصبى مصنوعى و رگرسيون خطى جند خانه

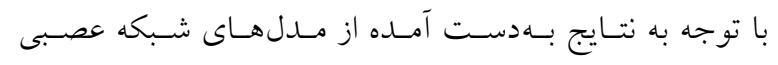

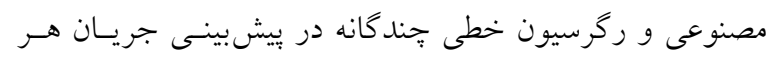
ماه، در اين بخش به بررسى تفـاوت عملكــرد ايسن مــدلهــا در

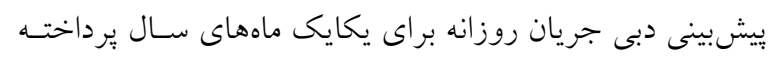




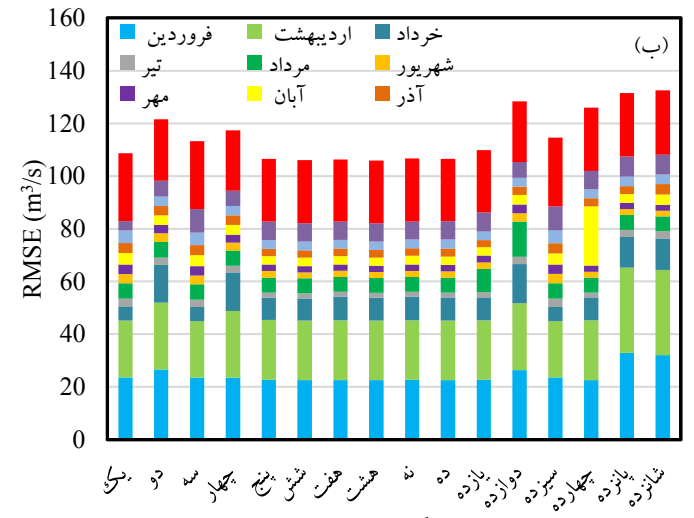

شماره تركيب ورودى

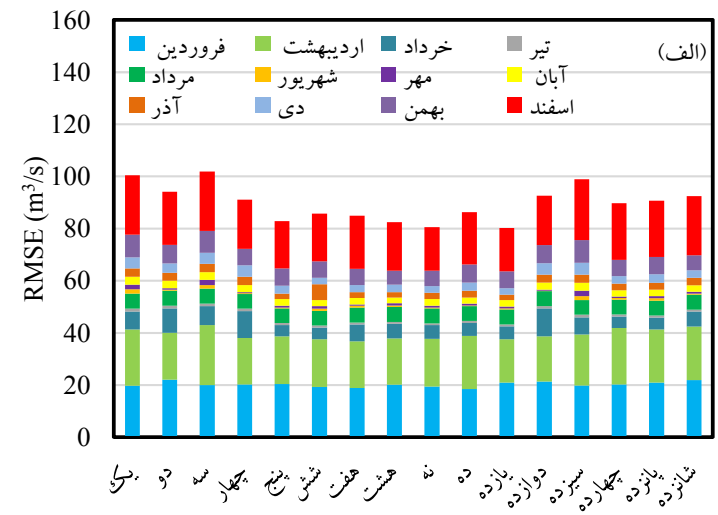

شماره تركيب ورودى

شكل 9. مقادير RMSE تجمعى دوره صحتسنجى بهازاى شانزده تركيب ورودى الف) ANN برسيون خطى جند گانه

تركيبى كه مجموع مقادير RMSE آن در دوازده ماه سال كمينسه

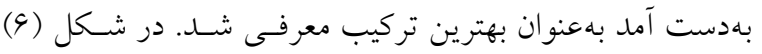

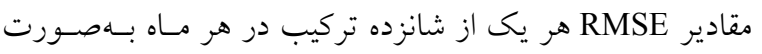
تجمعى نشان داده شده است.

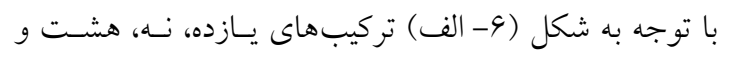

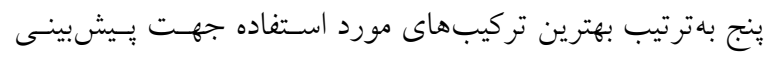

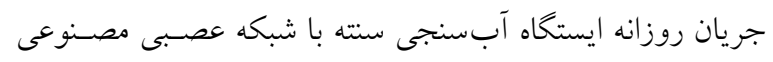

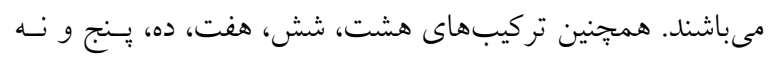

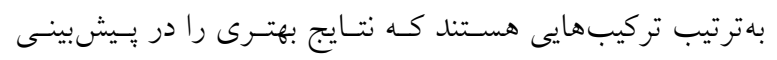

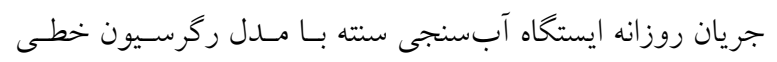

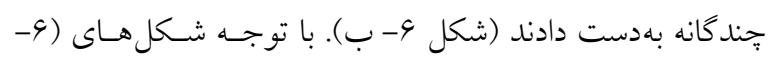

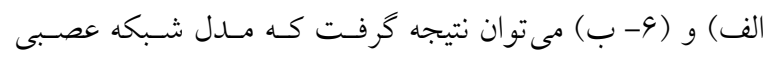

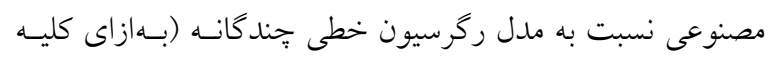
تركيبهاى ورودى) خطاى كمترى (در بيش بينى جريان) داشت.

\section{نتيجه گيرى}

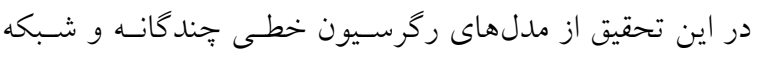

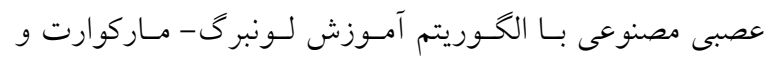

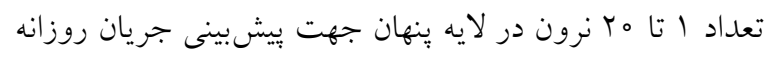

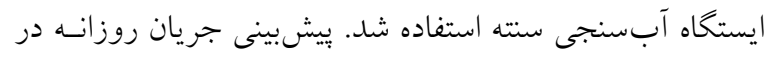

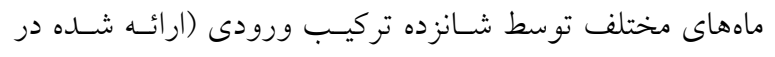

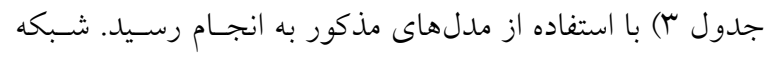

عملكرد مدل شـبكه عصسبى مصسنوعى بهتـر از عملكـرد مـدل

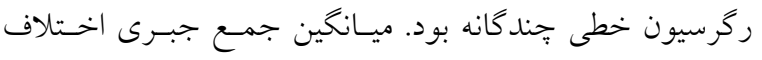

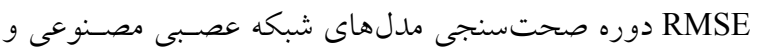

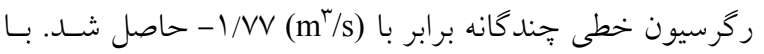
توجه جدولهاى (Y) و (D) مدل شبكه عصبى مصنوعى بهطسور

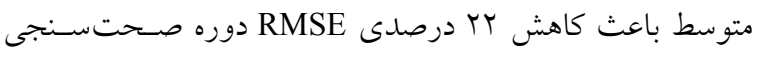
نسبت به مدل ركرسيون خطى جند كانه شد كه اين مقدار برابـر

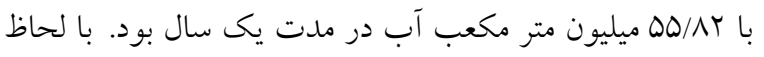

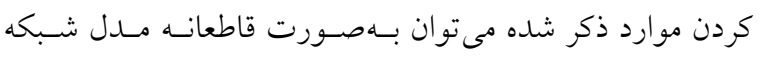
عصبى مصنوعى را بسيار دقيقتر و كم خطاتر از مدل ركرسيون

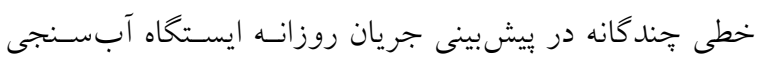

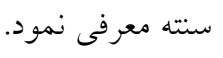

تحليل اثر تركيبهاى ورودى در عملكرد مدلها

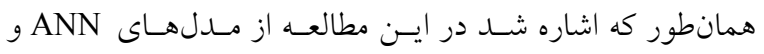
جLR

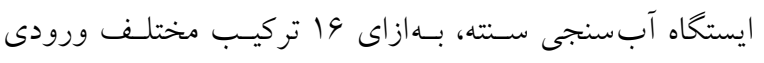

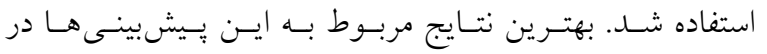

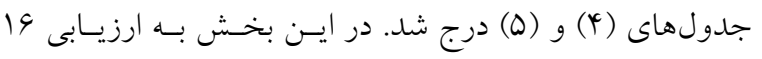

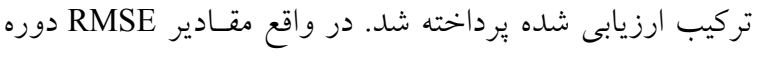

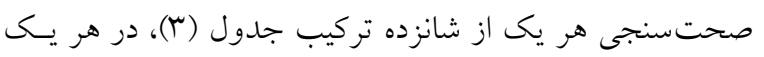

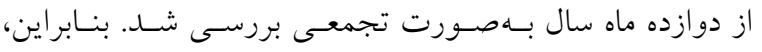


مدل ركرسيون خطى تجند كانه (در بيش بينى جريان روزانه) بود،

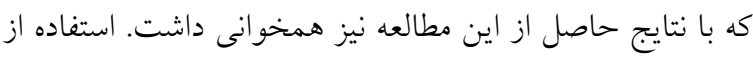

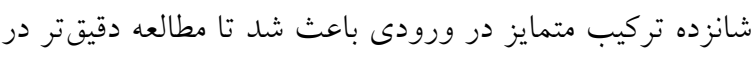

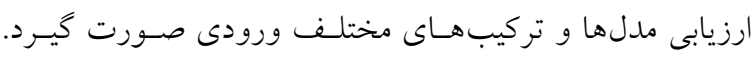

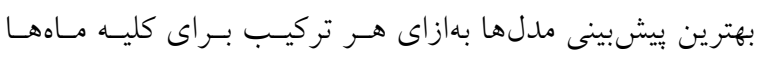

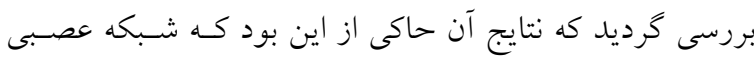
مصنوعى بهازاى تركيبهاى ورودى با شماره يازده، نه، هشت و

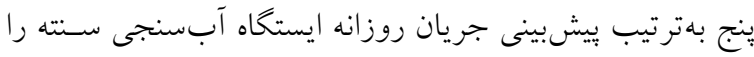

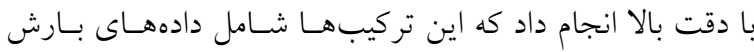

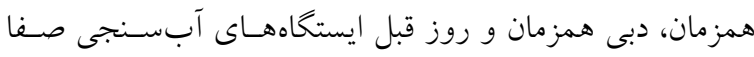

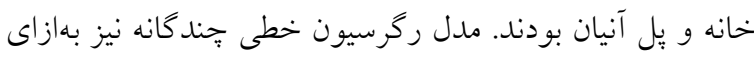
تركيب هاى با شماره هشت، شش، هفت، ده، بنج و نـه بهتـرين

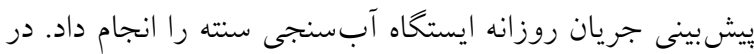

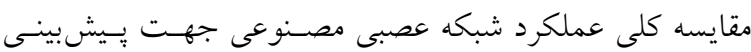
جريان روزانه كليه ماههـا بــازاى هـر يـك از شـانزده تركيـب

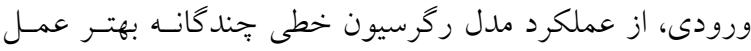

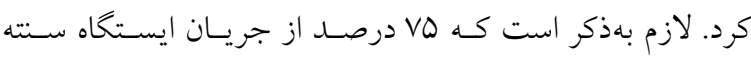

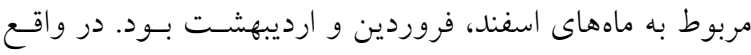
مدلى كه بتواند جريان اين سه ماه را بـا دقـت بيشـتر و خطــاى كمترى تخمين بزند بهعنوان مدل برتر جهت بيشبينى جريـان

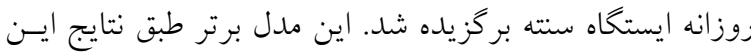
تحقيق مدل شبكه عصبى مصنوعى بود.
عصبى مصنوعى توانـايى زيـادى در يــيش بينى جريـان روزانـه

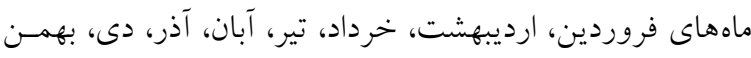

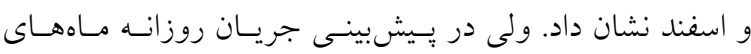

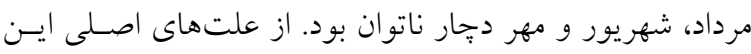

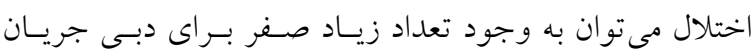

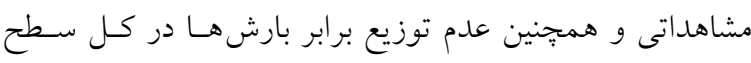

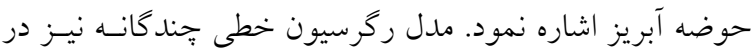

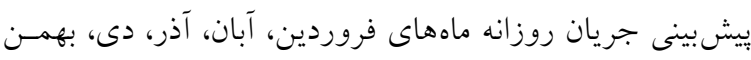

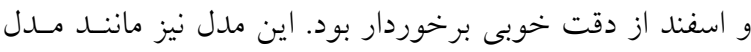

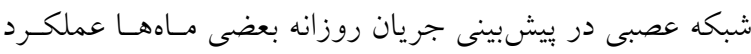

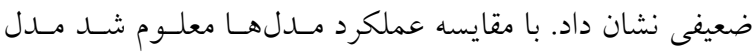

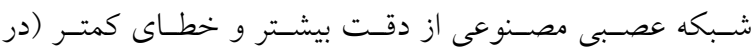

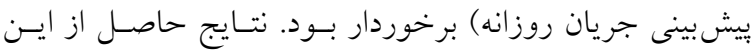

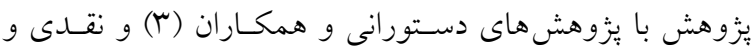

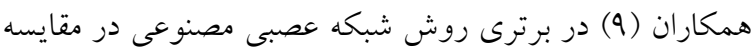

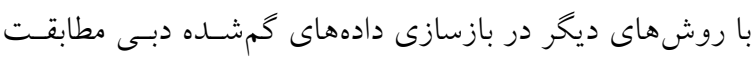

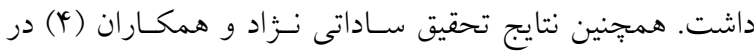

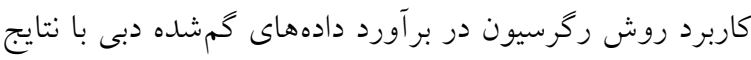
اين يُزوهش همخوانى داشت. همجنين نتايج مطالعـات ريـاد و

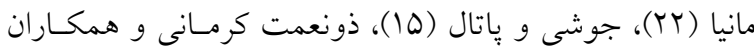

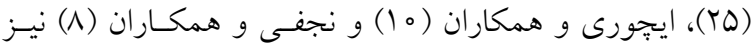
نشاندهنده عملكرد بهتر مدل شبكه عصبى مصنوعى نسـبت بـهـ

\section{منابع مورد استفاده}

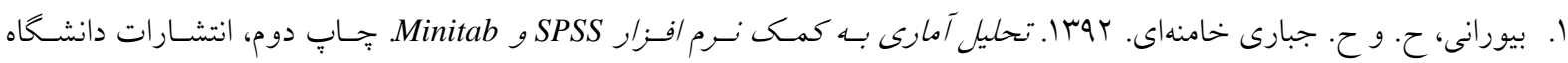

$$
\text { كردستان، سنتدج. }
$$

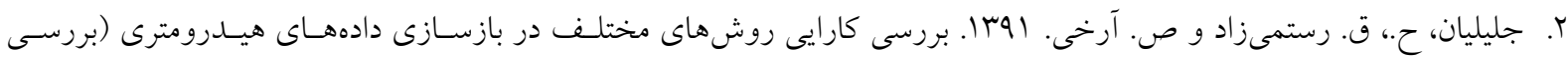

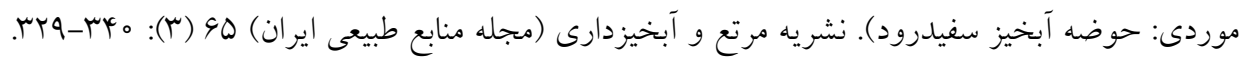

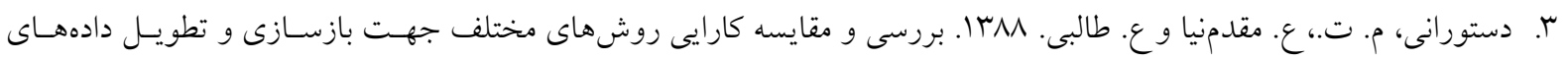

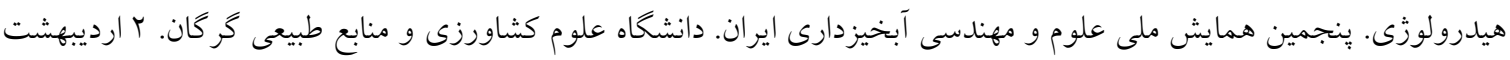

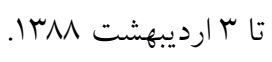

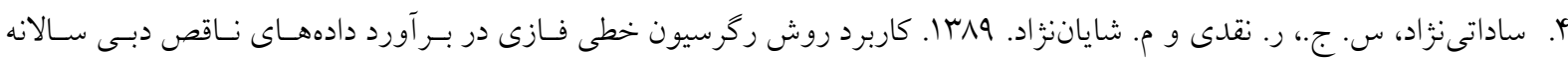




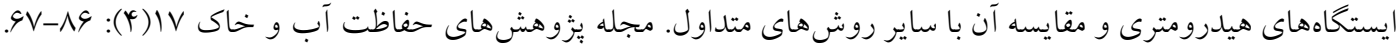

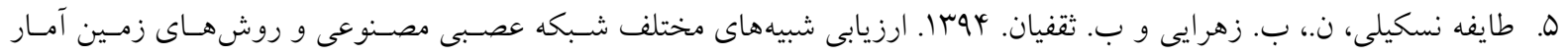

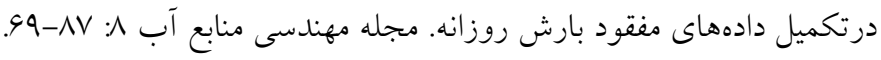

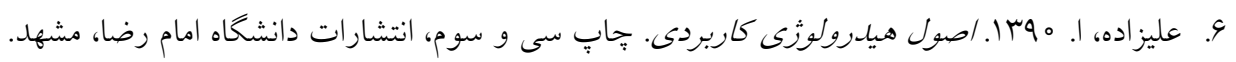

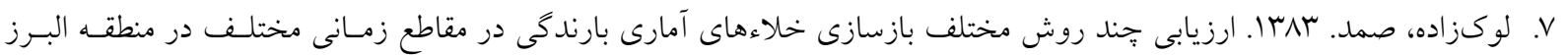

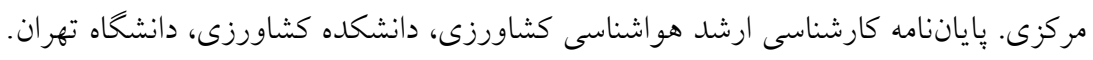

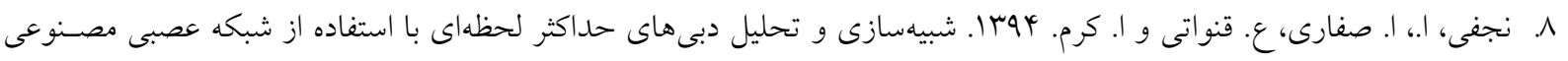

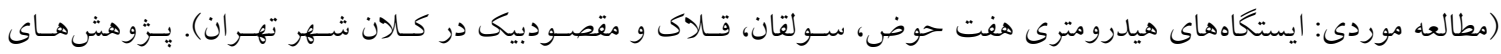

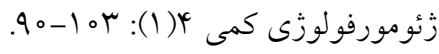

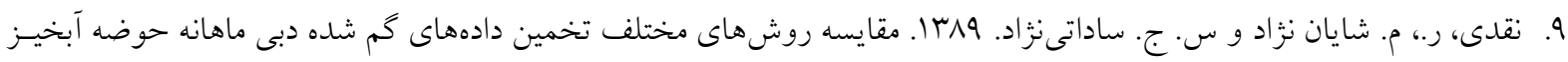

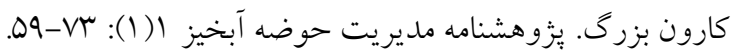

10. Aichouri, I., A. Hani, N. Bougherira, L. Djabri, H. Chaffai and S. Lallahem. 2015. River flow model using artificial neural networks. Energy Procedia 74: 1007-1014.

11. ASCE Task Committee on Application of Artificial Neural Networks in Hydrology. 2000. Artificial neural networks in hydrology, I: preliminary concepts. J. Hydrol. Eng. 5(2): 115-123.

12. Coulibaly, P., F. Anctil and B. Bobée. 2000. Daily reservoir inflow forecasting using artificial neural networks with stopped training approach. J. Hydrol. 230: 244-257.

13. El-Shafie, A., M. Mukhlisin, A. A. Najah and R. Taha. 2011. Performance of artificial neural network and regression techniques for rainfall-runoff prediction. Int. J. Math., Phys. Eng. Sci. 6(8): 1997-2003.

14. Gökbulak, F., K. Şengönül, Y. Serengil, I. Yurtseven, S. Özhan, H. K.Cigizoglu and B. Uygur. 2015. Comparison of rainfall-runoff relationship modeling using different methods in a forested watershed. Water Resour Manage. 29: 4229-4239.

15. Joshi, J. and V. M. Patel. 2011. Rainfall-runoff modeling using artificial neural network (A literature review). National Conference on Recent Trends in Engineering \& Technology, 13-14 May, India.

16. Kashani, M. H. and Dinpazhoh. Y. 2012. Evaluation of efficiency of different estimation methods for missing climatological data. Stoch Environ. Res. Risk Assess. 26: 59-71

17. Kothari, M. and K. D. Gharde. 2015. Application of ANN and Fuzzy logic algorithms for streamflow modeling of Savitri catchment. J. Earth Syst. Sci. 124(5): 933-943.

18. Machado, F., M. Mine, E. Kaviski and H. Fill. 2011. Monthly rainfall-runoff modelling using artificial neural networks. Hydrol. Sci. J. 56(3): 349-361.

19. Maidment, D. R. 1993. Handbook of hydrology. New York, McGraw-Hill.

20. Misra, D., T. Oommen, A. Agarwal and S. K. Mishra. 2009. Application and analysis of support vector machine based simulation for runoff and sediment yield. Biosystems Eng. 103(9): 527-535.

21. Modarres, R. 2009. Multi-criteria validation of artificial neural network rainfall-runoff modeling. Hydrol. Earth Syst. Sci. 13: 411-421.

22. Riad, S., J. Mania, L. Bouchaou and Y. Najjar. 2004. Rainfall-runoff model using an artificial neural network approach. Math Comput Model. 40: 839- 846.

23. Solaimani, K. 2009. Rainfall-runoff prediction based on artificial neural network (A case study: Jarahi watershed). Am.-Eurasian J. Agric. Environ. Sci. 5(6): 856-865.

24. Zealand, C. M., D. H. Burn and S. P. Simonovic. 1999. Short term stream flow forecasting using artificial neural networks. J. Hydrol. 214: 32-48.

25. Zounemat-kermani, M., O. Kisi and T. Rajaee. 2013. Performance of radial basis and LM-feed forward artificial neural networks for predicting daily watershed runoff. Applied Soft Computing 13: 4633-4644. 


\title{
Evaluation of Artificial Neural Network and Multiple Linear Regression Models to Estimate the Daily Missing data Flow (Runoff) in (Case Study: Santeh Gauging Station- Kordestan Province)
}

\author{
M. Isazadeh, P. Mohammadi* and Y. Dinpazhoh ${ }^{1}$
}

(Received: Aug. 04-2016 ; Accepted: March 07-2017)

\begin{abstract}
Statistical analysis and forecast discharge data play an important role in management and development of water systems. The most fundamental issues of statistical analysis and forecast discharge in Iran are lack of data in long term period and lack of stream flow data in gauging stations. Considering the issues mentioned in this study, we tried to estimate the daily data flow (runoff) of Santeh gauging station in Kordestan province using the nearby hydrometric and meteorological stations data. This estimation occurred based on the sixteen different input combinations, including data of daily flow of hydrometric stations Safakhaneh and Polanian and daily runoff in Santeh precipitation gauging station. In this research, the daily flow estimation of the Santeh station in each of the months of the year was evaluated for sixteen different combinations and artificial neural network models and multiple linear regressions. The performance of each model was evaluated with the indicators RMSE, CC, NS and t-student statistic. The results showed good performance of both models but the performance of the artificial neural network model was better than the regression model in estimation of the daily runoff in the most months of the year. Mean error of artificial neural network and multiple linear regression models was respectively estimated as 6.31 and $8.07 \mathrm{~m}^{3} / \mathrm{s}$ in the months of the year. It should be noted that the artificial neural network, for each sixteen combination used, had better result than the regression model.
\end{abstract}

Keywords: Artificial Neural Network, Estimating missing data, Multiple linear regression, Santeh station.

1. Dept. of Water Eng., Faculty of Agric., Tabriz Univ., Tabriz. Iran.

*: Corresponding Author, Email: mohammadi.parva@yahoo.com 